\title{
How Old Are the River Names of Europe? \\ A Glottochronological Approach
}

\author{
Carsten Peust (Konstanz)
}

\begin{abstract}
The names of large rivers are among the diachronically most stable of all words. The present glottochronological study aims to quantify the lexical preservation rate of this set of words, more specifically of the names of the largest rivers of Europe. 210 river names are taken into consideration. Their preservation rate during the past 2000 years turns out to have been about $87 \%$. Under the assumption that this observed rate can be extrapolated into the prehistoric periods, a statistical distribution of the name creation dates can be estimated. One conclusion is that $50 \%$ of the large modern rivers of Europe are likely to have received their present names prior to $8000 \mathrm{BC}$. This implies that the greater part of these names cannot be of IndoEuropean origin as has usually been assumed.
\end{abstract}

\section{Glottochronology}

There are two ways in which the vocabulary of a language can change with time. First, all words undergo continuous sound change, which often involves some kind of shortening. ${ }^{1}$ Second, words can be replaced by other words, either by items of the same language that changed their meaning or by items borrowed from other languages. ${ }^{2}$ The second type of change, namely lexical replacement, is a stochastic event. It cannot be predicted for a specific word when and by what it will be replaced, but it is conceivable to find a probability for it to be replaced during a given time interval. It is well known that different parts of the vocabulary are replaced at different probabilities. In particular, basic vocabulary is more stable than rare, specialized, or culture-dependent vocabulary. According to a hypothesis defended by Morris Swadesh, the replacement probability of a word is a function only of its semantic meaning, with no systematic influence of the specific language, genetic affiliation of the language or diachronic stage of the language to which the word belongs. The famous 100-item Swadesh list ${ }^{3}$ comprising 100 concepts of the basic vocabulary was estimated to have an average preservation rate of approximately $0.86(86 \%)$ per millennium in an average language.

This is a stochastic statement which, as is characteristic of stochastic statements in general, does not apply to each single item (here: language). Under special circumstances, the lexical replacement rate of a language may be accelerated (e. g. by strong influence from contact lan-

\footnotetext{
${ }^{1}$ E. g. head $<$ Old English hẽafod, to mention only one out of innumerable examples.

${ }^{2}$ E. g. you, originally a plural form that expanded its meaning so as to replace the original singular pronoun thou, or mountain, a loan from French which replaced an older English word of the same meaning (now an obsolete term barrow).

${ }^{3}$ Swadesh (1955).
} 
guages) or retarded (e. g. when an earlier version of the same language serves as the literary norm). Based on such counterexamples, there has been much critique to Swadesh's approach. I am aware that glottochronology is a highly controversial method and has been criticized at times very harshly. ${ }^{4}$ The most frequent objection has been to deny that the lexicon changes at a constant rate. This objection is, however, unjustified because it does not account for the statistical character of the claim. While the wording by Swadesh himself is not always very precise mathematically, ${ }^{5}$ I understand that, contrary to what has often been purported, Swadesh did not have an absolutely constant preservation rate in mind, but rather a reasonable average rate that admits some amount of statistical variation. ${ }^{6}$ This already follows from his very term "lexico-statistics", as also from the nature of radiocarbon dating to which he compared his method. If so understood, lexicostatistic procedures will lose much of their dubious reputation. Even if we reject the idea of a constant rate of change, it will nonetheless be possible to compute a statistical average value out of rates that have been observed, and it should be obvious that such an average value can be used if treated with the same care as is appropriate to any statistical assertion.

In essence, glottochronology is thus about creating a statistical model from things known and applying it to the unknown. This is a legitimate procedure, in fact the best available one in the absence of data about the unknown. As the model is more fuzzy, the results will become less reliable. Nevertheless, they will offer the best possible approximation to truth and should therefore be regarded as the default hypothesis until new evidence appears. The lexicostatistical method can therefore be applied even without having to insist on a strictly constant rate of lexical change.

\section{The logarithmic Swadesh formula and its amendment}

Departing from a preservation rate of 0.86 per millennium, Swadesh (1955) and most of his successors assumed that after a time interval of $m$ millennia, the rate of preserved words in Swadesh's 100-item list should be $0.86^{m}$. The discipline of glottochronology has used this formula to estimate the time distance between related languages. For this purpose, word lists of two languages are assembled, and the rate $r$ of shared cognates is measured. ${ }^{7}$ An observed rate $r$ of shared cognates is then assumed to imply that the total time distance between both languages is $\log r / \log 0.86$ millennia. The may mean that one of the languages is a child of the other separated by this distance in time, or that both languages are independent derivatives from a common ancestor, the distance on each branch being half of the total distance.

There is a mathematical flaw in this formula that has usually been overlooked. In any given word list, the preservation probability is not equal for all items, but the list is composed of items with different degrees of stability. The preservation rates of the list items form a statisti-

\footnotetext{
${ }^{4}$ E. g.: "Sprachgeschichte in Formeln fassen zu wollen ist Utopie und grenzt an Wissenschaftsdichtung (science fiction)" (Penzl 1985: 156).

${ }^{5}$ A typical formulation: "universal everyday vocabulary, words of the type comprising the test list, changes at a roughly constant rate" (Swadesh 1952: 455).

6 "It is to be expected that a certain amount of fluctuation in the calculated rate of vocabulary retention will remain, even after the obvious specific sources of error are eliminated. At least in part this variation is the usual 'variance' found in all statistical phenomena" (Swadesh 1952: 458).

${ }^{7}$ This task can be intricate because the cognacy judgements require knowledge about the historical developments of the languages concerned. As the time distance between languages increases, cognacy judgements become less certain.
} 
cal distribution around some average value. The empirically measured preservation rate of the list as a whole is just an estimation of this average value. The point is that, while two probabilities can be multiplied to find their combined probability (which leads to a logarithmic formula as the one cited above), the average of the combination of two probability distributions is not simply the product of both their averages.

I intend to clarify the mathematical aspects of this issue elsewhere in more detail and will illustrate the problem here only by means of a very simple example. Let there be a Swadesh list of two items. Let the real preservation probabilities per millennium of these items be 0.7 and 0.9 respectively. In real life, we cannot know the probabilities beforehand but have to determine them from empirical language data, that is by counting cognates within related languages whose time distance is known. If the data base is large enough, we will obviously find the average preservation probability per millennium of our word list as a whole as being close to $(0.7+0.9) / 2=0.8$.

Now consider the preservation rate of the same word list for languages whose time distance is two millennia. The preservation probability after two millennia will be $0.7^{2}$ for the first item and $0.9^{2}$ for the second. The preservation probability of the whole list after two millennia therefore turns out to be $\left(0.7^{2}+0.9^{2}\right) / 2=0.65$, and not $0.8^{2}=0.64$ as many would have expected.

More generally, if the preservation probability of a word list per millennium is $p$, the preservation probability after $m$ millennia (with $m>1$ ) will not be $=p^{m}$, as has commonly been assumed, but $>p^{m}$. This implies that the estimations of time depths in practically all existing applications of glottochronology have been to low. ${ }^{8}$

It is difficult to quantify this effect in an exact manner, since this would require, alongside with the empirically measured average preservation rate of the word list, at least one additional constant representing the internal heterogeneity of that list, which would likewise have to be determined empirically. ${ }^{9}$ Let it suffice here to say that the preservation probability after $m$ millennia (for $m>1$ ) will be higher, to an unknown extent, than $p^{m}$; or that for an observed preservation rate $r$ the distance in time will be higher, to an unknown extent, than $\log r / \log p$.

\section{$3 \quad$ River names and glottochronology}

I will now estimate the preservation rate of one specific word list, namely a list of the names of the major rivers of Europe. This will allow us to estimate a distribution of the dates at which these names came into existence. Due to the mathematical effect described in the preceding section, the distribution is not going to suggest absolute dates, but can only suggest a threshold stating that a given number of names are likely to exceed (to an unknown extent) a specific age.

\footnotetext{
${ }^{8}$ This is true for time depths greater than the intervals on which the preservation rate of the list was calibrated. For smaller time depths, the estimations will be too high.

${ }^{9}$ Or, even worse, each single meaning would require its own constant, all of which would have to be determined empirically. A mathematical framework for estimating the constants for all meanings of a list individually was proposed by Dyen, James and Cole (1975), who recognized the mathematical problem addressed here, but this framework has, to my knowledge, never been applied by others. I believe that it cannot be applied in practice because the linguistic data are never abundant enough to estimate so many independent variables. Dyen, Kruskal and Black (1992: 7) again recognized the mathematical problem but refrained from providing a solution.
} 
River names are widely recognized as being the diachronically most stable of all words. ${ }^{10}$ Most rivers still have the same names today as attested in the earliest available records. This is true in particular for large ${ }^{11}$ rivers, whose names are replaced even more rarely than those of small rivers. Names of large rivers are normally retained even when the area is invaded by speakers of another language. Factors contributing to their extraordinary stability include:

- Their semantic isolation. While it is easy for a word to undergo a meaning shift such as 'to think' > 'to believe', 'to want' > 'to love', 'green' > 'yellow', 'woman' > 'wife', etc., it would be much harder for a river name to change its meaning from 'Rhine' to 'Danube', or to any other meaning. ${ }^{12}$

- Names of large rivers are known to a large number of people, possibly speaking different languages. Even if some of them invent a new name, this new name will not readily be adopted by all peoples concerned.

- While names of small rivers may be forgotten and need to be reinvented after a temporary depopulation of an area, names of large rivers do not elapse completely from human memory.

\section{$4 \quad$ Selection of rivers}

The preservation rate of river names must be estimated empirically on the basis of rivers attested in ancient records. While this could be attempted for several regions of the world, I will limit myself to the rivers of Europe, many of which were mentioned in classical Greek or Latin sources which are about 2000 years old. 2000 years is therefore the time span for which the preservation rate will be calibrated.

Swadesh's hypothesis predicts that the results would not differ a lot if rivers of other parts of the globe were examined for which records of a similar age are available. I have to leave this for others to test. ${ }^{13}$

\footnotetext{
${ }^{10}$ Four citations may suffice: "C'est la rivière qui résiste le mieux aux substitutions, car elle échappe en général aux changements d'ordre officiel; d'autre part, elle a une individualité plus nette que la montagne ou le lieu dit, dont les limites sont plus imprécises, ou même que la ville, qui peut se déplacer plus ou moins. C'est ainsi qu'en France la très grande majorité des noms de fleuves et de rivières sont celtiques ou préceltiques" (Dauzat 1926: 41); "[Es] soll hervorgehoben werden, daß als die dauerhaftesten und altertümlichsten unter allen Eigennamen, dauerhafter als Siedlungsnamen und altertümlicher selbst als Gebirgsbezeichnungen, sich die Gewässernamen erwiesen haben" (Krahe 1954: 46); "Най-устойчиви от всички местни имена са названията на големите реки: те се пазят най-дълго време, независимо от смяната на населението" (Georgiev 1960: 21); "Gewässernamen (= Hydronyme) sind innerhalb der Onomastik häufig Gegenstand gesonderter Untersuchungen. Dies hat seinen Grund [...] darin, dass Fluss- und Seenamen häufig ein besonders hohes Alter besitzen. Sie können häufig aus der Sprache, die an den Ufern der Gewässer gesprochen wird oder in deren Vorstufen gesprochen wurde, nicht mehr erklärt werden und setzen sich dadurch von den Siedlungs- und Flurnamen deutlich ab" (Udolph 2004: 329).

${ }^{11}$ I define large as 'long' here, simply because the lengths of rivers are easy to retrieve.

12 The exact geographical extension of what to consider a single river can change more easily. It happens, for instance, that two differently named, adjacent parts A and B of one course of water aquire a single name, either that of A or that of B (as in $\Rightarrow$ Donau; this is what Schramm 1981: 67f. calls "Namensausgleich"), that what used to be considered as one single river comes to be seen as two rivers $\mathrm{A}$ and $\mathrm{B}$ with distinct names (as in $\Rightarrow W e s e r$ ), or that when two rivers $\mathrm{A}$ and $\mathrm{B}$ of roughly equal size confluence into a river $\mathrm{C}$, there is hesitation as to whether A or B should bear the same name as C (cf. $\Rightarrow$ Severskij Donec).

${ }^{13}$ East Asia or India would be areas with sufficient historical records, but I am not personally familiar with these. The three rivers with the absolutely oldest attestations on earth are Euphrates, Tigris, and Nile. The Euphrates (Arabic al-Furāt) and the Tigris (Arabic Diğla) bore their present names already in Sumerian sources of the 3rd
} 
Within Europe, I consider all rivers exceeding $250 \mathrm{~km}$ in length ${ }^{14}$ that flow into the Atlantic Ocean, the Mediterranean Sea, the Black Sea or the Baltic Sea. There are 210 of them. By contrast, rivers flowing - directly or indirectly - into the Caspian Sea (such as Vólga, Urál and their tributaries) and the Arctic Sea (such as Pečóra, Výčegda) are disregarded, because most of them are located too far away from the Classical world to have been mentioned in the ancient sources. In this respect, "Europe" is taken here in a narrower sense than usual.

\section{$5 \quad$ The data table}

The following table enumerates the longest rivers of Europe, as defined above, sorted by length, together with their ancient names if attested. "Ancient" is taken as approximately 2000 years old. These names are attested in the works of Herodotus (5th century BC), Caesar (1st century BC), Strabon (around 0), Plinius (1st century AD) and other authors of that time. I still accept the numerous records in Ptolemaios' Geographike (2nd century AD) as being roughly 2000 years old, but not so records from Late Antiquity or Byzantine times. Attestations of the ancient names are, for the most part, easy to find. My standard sources are Wissowa et al. (1894-2000) and Talbert (2000). Explicit references will only be provided where they do not suffice. The entries in the rightmost column are to be read as follows:

'yes': An ancient name is attested, the river has one or more modern names, and the ancient name has survived in the modern name (or in one of the modern names).

'(yes)': More than one ancient names are attested for the same river, and only one of them has survived to the present day.

'no': An ancient name is attested, but the modern name is a different one.

'-': No ancient name is attested for this river, so that the age of the modern name cannot be judged.

millennium BC (buranun and idigna, respectively; note that $i d_{2}$ is the Sumerian noun for 'river', so that the name core of the river Tigris is probably just -igna). The river Nile, however, changed its name more than once (cf. Peust 2010: 68f.). The reason may be that its name, the Nile being the only river of Egypt, was perceived as an appellative for 'river' rather than a proper name, and thus did not share the conservativity so characteristic of hydronyms.

${ }^{14}$ River lengths are not absolutely straightforward to measure, so that some amount of uncertainty remains. This does not disturb my argument with the exception of possibly a small number of rivers whose length comes close to the $250 \mathrm{~km}$ limit. I took my data on river lengths for the most part from Wikipedia. 


\begin{tabular}{|c|c|c|c|c|}
\hline No. & Modern name(s) & Ancient name(s) & $\begin{array}{l}\text { Length } \\
\text { in } \mathbf{k m}\end{array}$ & $\begin{array}{l}\text { Ancient } \\
\text { name sur- } \\
\text { vived? }\end{array}$ \\
\hline 1 & $\begin{array}{l}\text { (Germ.) Donau / (Hungar.) } \\
\text { Duna / (Slovak) Dunaj / } \\
\text { (Serb.) Dünav / (Bulgar.) } \\
\text { Dúnav / (Roman.) } \\
\text { Dúnăre } 15\end{array}$ & $\begin{array}{l}\text { (upper river:) (Latin) Danuvius } \\
\text { (lower river:) (Greek) Istros }{ }^{16} / \\
\text { (Latin) (H)ister }\end{array}$ & 2860 & $(y e s)^{17}$ \\
\hline 2 & $\begin{array}{l}\text { (Russ.) Dnepr / (Ukrain.) } \\
\text { Dnipró }^{18}\end{array}$ & (Greek) Borysthenēs & 2290 & no \\
\hline 3 & (Russ.) Don $^{19}$ & (Greek) Tanaïs & 1950 & yes \\
\hline 4 & $\begin{array}{l}\text { (Russ.) Dnestr / (Ukrain.) } \\
\text { Dnistér / (Roman.) Nistru }{ }^{20}\end{array}$ & (Greek) Tyras & 1360 & yes \\
\hline
\end{tabular}

${ }^{15}$ Medieval German spelling Tinnowa (Borchers 2006: 14-17). This form appears to be the regular outcome of an earlier *Dōn- with the High German sound shifts $d>t$ and $\bar{o}>u o>\bar{u}$. We would thus expect the modern German name to be *Tūn-, but we find Dōn- which looks like a return to the Pre-German form. This development has been explained, not entirely convincingly, by local dialect influence (Reichardt 1985). An alternative explanation might be that the modern German name was transmitted via a non-German (Slavonic?) population.

Here, as in several of the names treated below (Bosna, Južnyj Bug, Don, Hron, Olt, Osam, Morava, Mureş, Someş, Somme), which are located in South-Eastern Europe for the most part, we find a vowel - $a$ - of the ancient sources reflected as $-o-$ or even $-u$ - in the modern languages. Sound shifts $a>o$ are attested in some branches of Indo-European (e. g. $\bar{a}>\bar{o}$ in Germanic and Albanian, $\breve{a}>\breve{o}$ in Slavonic), but it remains to be worked out to which languages these sound shifts are to be ascribed in the individual river names. As for the name of the Danube, Georgiev (1966: 189) assumes an influence of Dacian, whereas Schramm (1973: 37-43 and 1981: 231-233) believes that this name was transmitted to the Slavs by speakers of a Germanic (Gothic) language. As evidenced by the German form, the name of the Danube requires positing a long $\bar{a} / \bar{o}$ as its first vowel. This is supported by the Latin poets, who treat this vowel as metrically long (e. g. Cédere Dānuvius sē tibi Nìle negat, a pentameter from Ovid, Tristia ex Ponto). The further sound shift towards $u$ in this name is likely due to the influence of an early Slavonic language. The Slavonic languages represent Proto-Indo-European $* \bar{o}$ as $\bar{a}$ and $* a u$ as $\bar{u}$. We can assume (with Holzer 2007: 59 and Schramm 1981: 144f.) that there was a time at which the shift $\bar{o}>\bar{a}$ had already been completed, whereas the shift *au $>\bar{u}$ had only reached an intermediate stage $* \bar{o}$. At that time, the first vowel of the name of the Danube could have been identified by Slavonic settlers with their $* \bar{o}$, which subsequently shifted to $\bar{u}$ and, after the loss of the original length contrasts in Slavonic, was borrowed as $u$ into languages such as Hungarian and Romanian. A shift of borrowed ${ }^{*} \bar{o}$ to $\bar{u}$ also took place in Russian búkva 'letter of the alphabet' < Gothic bōka (idem). The origin of $-r$ - in the Romanian name has no definite explanation (see Georgiev 1966: 193 and Schramm 1973: 43-47 and 1981: 230 for proposals).

${ }^{16}$ Here and in the following, I cite forms from Ancient Greek without accent marks, since these marks are not usually attested in the original manuscripts but were supplied by modern editors (cf. Clarysse 1997). We have no reliable knowledge about how the ancient Greeks accentuated foreign names.

${ }^{17}$ Only the ancient term for the upper river has survived, having been extended to the river as a whole.

${ }^{18}$ The modern name is first attested in 6th century Greek as Danapris and is spelled Døntpro in Old Russian (cf. Fasmer 1964-87, I: 518; Nepokupnyj et al. 1979: 173). The early Slavonic pronunciation must be reconstructed approximately as Dunäprí. On this river name $\Rightarrow$ also below in section 9 .

${ }^{19}$ On this river name $\Rightarrow$ below in section 9 . On the phonetic development $\Rightarrow$ Donau.

${ }^{20}$ The modern name first appears in the 4th century as (Latin) Danastius (cf. Fasmer 1964-87, I: 518f.; Nepokupnyj et al. 1979: 173f.; $-r$ - possibly omitted by error). The ancient name Tyras was preserved up into Osmanic Turkish as Turla but is now obsolete. A diminutive derivation survives to the present day in the name of the Turunčúk, a tributary to the Dnestr.

Since the initial segment $d n$ - of the modern name is almost certainly a former term for 'river' ( $\Rightarrow$ below in section 9), the remaining -estr is similar enough to the ancient name to make it probable that it in fact continues that name. This is what Schmid (1976: 439f.) envisages who suggests that the second part might be an Iranian reinterpretation (cf. Ossetian cestyr 'big') based on the ancient Tyr-. I wish to forward an alternative proposal that $-s-$ could be the remnant of an Indo-European nominative case ending, here preserved in liaison as opposed to the loss of the same ending in final position, so that the modern name would derive from a compound * $d^{\breve{n a} s-t u r a ̆ s}$ 'river Turas'. 


\begin{tabular}{|c|c|c|c|c|}
\hline No. & Modern name(s) & Ancient name(s) & $\begin{array}{l}\text { Length } \\
\text { in } \mathbf{k m}\end{array}$ & $\begin{array}{l}\text { Ancient } \\
\text { name sur- } \\
\text { vived? }\end{array}$ \\
\hline 5 & $\begin{array}{l}\text { (Germ.) Rhein / (French) } \\
\text { Rhin / (Dutch) Rijn }{ }^{21}\end{array}$ & (Lat.) Rhenus & 1230 & yes \\
\hline 6 & (Russ.; Ukrain.) Desná ${ }^{22}$ & - & 1130 & - \\
\hline 7 & $\begin{array}{l}\text { (Germ.) Elbe / (Czech) } \\
\text { Labe / (Sorbian) Eobjo }\end{array}$ & (Lat.) Albis & 1090 & yes \\
\hline 8 & $\begin{array}{l}\text { (Pol.) Wisła / (Germ.) } \\
\text { Weichsel }^{24}\end{array}$ & (Lat.) Vist(u)la & 1050 & yes \\
\hline 9 & $\begin{array}{l}\text { (Russ.) Séverskij Donéc / } \\
\text { (Ukrain.) Sívers'kyj } \\
\text { Donéc }\end{array}$ & (Greek) Hyrgis & 1050 & no \\
\hline 10 & $\begin{array}{l}\text { (Span.) Tajo / (Portug.) } \\
\text { Tejo }^{26}\end{array}$ & (Lat.) Tagus & 1040 & yes \\
\hline
\end{tabular}

${ }^{21}$ The Latin spelling with $R h$ - is noteworthy. The received explanation (e. g. Krahe 1964: 95f.) assumes an influence of Greek orthography. But sources of the Old High German period write the name with Hr- (Hrenus Hrin; Borchers 2006: 56f.), which was a regular notation in Old High German to denote a sound different from $r$-, either a cluster $/ h r /$ or possibly a voiceless $[r]-$. This spelling certainly cannot be ascribed to Greek orthographical practice. Is it possible that the local (probably Celtic) population pronounced the name with an initial voiceless $r$-, which was adopted as such into Old High German and which was rendered as $R h$ - by the Romans? $R_{\circ}$ (spelled $r h$-) is still a common sound in Welsh, another Celtic language, particularly in word-initial position $\left(r\right.$ - is in fact the regular Welsh representation of an Indo-European initial $\left.*_{r-}\right)$. A similar argument may apply to $\Rightarrow$ Rhône.

As for the stem vowel, all modern names (including the Swiss German dialect form $/ r \bar{\imath} /$ ) presuppose an earlier $-\bar{l}-$ which contrasts with $-\bar{e}$ - of the Latin attestation. It can be assumed either that the original name contained a Pro-

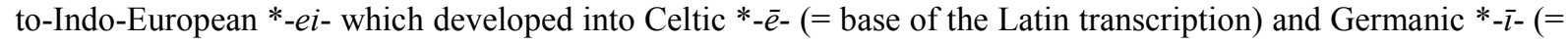
base of all modern name forms) (thus Krahe 1954: 42; Jung 1970: 440 and others), or that the name originally had a Proto-Indo-European $*_{-} \bar{e}-$ which survived as such in Latin and developed into Celtic $*_{-} \overline{-}-(=$ base of all modern name forms).

${ }^{22}$ The name Desna, which appears several times as a hydronym across the Slavonic territory, might be explained from a (South) Slavonic term for 'right (hand)' although, in modern terminology, Desna is the left tributary of the Dnepr. Tolstoj (1984) discusses examples for Desna and for rivers that would allow for a Slavonic translation as 'left (hand)' (Leva, Levaja, Šuja etc.), finding that most 'right' rivers are actually left tributaries of a larger river and most 'left' rivers are right tributaries, although there are some exceptions to this principle of inversion that he needs to explain away. Tolstoj explains this inversion from naming habits of the older Slavonic peoples who, contrary to modern hydrographical usage, would have viewed rivers in streamupward direction.

I am sceptical about this argumentation. All rivers so named are isolate examples, there being no pair of neighboured, opposing tributaries that would bear both names 'right' and 'left'. This raises the suspicion that these names aquired their present shapes by folk-etymological reinterpretation of older names rather than by original coinage.

${ }^{23}$ For similar names of other rivers cf. Krahe (1964: 52f.). Several scholars have identified this name with Old Norse $e l f r=$ Swedish $\ddot{l} l v$ 'river' and some (e. g. Krahe, Kitson 1996: 75) further with Latin albus 'white'.

${ }^{24}$ For details and considerations on the original name form see Udolph (1990: 303-311).

${ }^{25}$ Donec is a diminutive form of the $\Rightarrow$ Don, of which it is a tributary. The diminutive name form has been attested since the 16th century, whereas in earlier sources the Severskij Donec was either called 'small Don' or considered a part of the Don (cf. Nepokupnyj et al. 1979: 503; Pospelov 1998: 377). It is rather common for a tributary $B$ of a river $A$ to be named by a diminutive derivation of $A$ (e. g. Bužok as a diminutive of $\Rightarrow J u z ̌ n y j$ Bug; $\Rightarrow$ Ingulec as a diminutive of $\Rightarrow$ Ingul; $\Rightarrow$ Moselle as a diminutive of $\Rightarrow$ Meuse; Mürz as a diminutive of $\Rightarrow$ Mur; see also $\Rightarrow$ Dnestr). As explained by Pospelov, the attribute Severskij does not, as it might seem today, mean 'northern' (which would not make sense geographically), but was derived from the name of a people settling in that area.

${ }^{26}$ The Portuguese name is pronounced $/ t \varepsilon z u /$. This name and other toponyms in the Iberian peninsula evidence striking phonetic developments that differ from the regular sound shifts of the inherited vocabulary. In topo- 


\begin{tabular}{|c|c|c|c|c|}
\hline No. & Modern name(s) & Ancient name(s) & $\begin{array}{l}\text { Length } \\
\text { in } \mathbf{k m}\end{array}$ & $\begin{array}{l}\text { Ancient } \\
\text { name sur- } \\
\text { vived? }\end{array}$ \\
\hline 11 & $\begin{array}{l}\text { (Russ.) Západnaja Dviná / } \\
\text { (Latv.) Daugava / (Germ.) } \\
\text { Düna }^{27}\end{array}$ & - & 1020 & - \\
\hline 12 & (French) Loire ${ }^{28}$ & (Lat.) Liger & 1010 & yes \\
\hline 13 & $\begin{array}{l}\text { (Croat.; Serb.) Sáva / } \\
\text { (Sloven.) Sava }\end{array}$ & (Lat.) Savus & 990 & yes \\
\hline 14 & (Russ.) Xop'ó $r^{30}$ & - & 980 & - \\
\hline 15 & $\begin{array}{l}\text { (Ukrain.) Týsa / (Hungar.) } \\
\text { Tisza / (Serb.) Tisa }\end{array}$ & $\begin{array}{l}\text { (Lat.) Pathissus } \sim \text { Parthiscus, } \\
\text { later (6th cent.) Tisia which } \\
\text { seems to be an abbreviation } \\
\text { thereof }^{31}\end{array}$ & 960 & yes \\
\hline 16 & (Roman.; Ukrain.) Prut & (Greek) Pyretos ${ }^{32}$ & 950 & yes \\
\hline 17 & $\begin{array}{l}\text { (Russ.) Néman / (Lithuan.) } \\
\text { Nemunas / (Germ.) Me- } \\
\text { mel }^{33}\end{array}$ & - & 940 & - \\
\hline
\end{tabular}

nyms, ancient $a$ can be reflected as $e$, and ancient $g$ and $s$ as Portuguese $/ z / \sim$ Spanish $/ x /$ (written $g$ or $j$ ), whereas Latin $a, g$ and $s$ are generally retained as such in common vocabulary. Other testimonies for these peculiar developments include $\Rightarrow$ Esla, $\Rightarrow$ Genil, $\Rightarrow$ Júcar, some names of smaller rivers not discussed in the present article such as Jalón < Salo, Sella < Salia, Tâmega < Tamaga, and the name of the Portuguese town Beja $<$ Paca. (But note that Latin $s>$ Spanish $j$ is found as a sporadic sound change in a few items of the common vocabulary as well, such as Span. pájaro 'bird' < Lat. passer.)

These peculiarities have traditionally been explained (e. g. by Meyer-Lübke 1930: 416f.; Guérios 1956: 142f.; Coutinho 1967: 193) by the assumption that these proper names were arabicised during the Muslim rule over the Iberian peninsula. The Romance phonemes $/ a /, / g /$ and $/ s /$ would thus have been realized as $[\propto]$, $[\check{g}]$ and $[\check{s}]$, for which modern continuations as $/ e /, \mid z \sim x /$ and $/ z \sim x /$ would be conceivable. But it is hard to see why Arabic pronunciation habits should have affected Spanish or Portuguese toponyms more easily than Spanish or Portuguese appellatives. I consider it more probable that sounds such as $\alpha, \check{g}$ and $\breve{s}$ existed in these names already in antiquity, of which the Latin spellings were only approximate notations.

${ }^{27}$ First attested as Duna by Saxo Grammaticus (12th cent.). On this river name $\Rightarrow$ below in section 9.

${ }^{28}$ French oi (here and in $\Rightarrow$ Oise) is the regular outcome of a Latin short $\breve{l}$.

${ }^{29}$ For similar names of other rivers cf. Krahe (1964: 50).

${ }^{30}$ First attested in the 14th century as Poxor (Pospelov 1998: 450).

${ }^{31}$ I follow Pospelov's (1998: 417) suggestion that the initial element was misunderstood as a preposition po 'on' by a speakers of a Slavonic language. By contrast, Georgiev (1961: 91f.) does not consider the early name forms with $P$ - to be related. He believes that the name might originally have contained a medial consonant and thus was identical to the name of the $\Rightarrow$ Temeş.

${ }^{32}$ Most likely the source of the modern name despite difficult vowel correspondences. A 10th century Greek source (cited by Schramm) attests both varieties side by side as Bourat $\sim$ Broutos. Former explanations of this variation include a secondary assimilation to the name of the $\Rightarrow$ Răut (cf. Schramm 1973: 49-54) or an apophony on the level of Proto-Indo-European (*purnt > Pyretos/Bourat vs. *puront > Prut/Broutos, cf. Schmid 1976: 438). I wish to forward a third and perhaps easier suggestion that Prut may have developed from an earlier *Purt by the well-known Slavonic liquid metathesis whose effect we also observe in Labe for $\Rightarrow$ Elbe and in $\Rightarrow$ Lyna for Alna.

${ }^{33}$ The $-a$ - of the Russian form is a false orthography for $*_{-} o-$, both of which merge in unstressed position. This vowel, which is mobile in the name forms of Belorussian (N'óman, genitive N'ómna) and Polish (Niemen, genitive Niemna), must reflect an earlier $*_{b}(\breve{u})$ (c.f. Fasmer 1964-87, III: 61), which agrees perfectly with the Lithuanian form. The German name seems to be related in some way, too. Balaišis (1987) believes that it originated from the Balto-Slavic form by deformation of sonorants. In any case, the German variant is the earliest attested one: Mimila $\sim$ Mimele $\sim$ Memele (13th cent.). 


\begin{tabular}{|c|c|c|c|c|}
\hline No. & Modern name(s) & Ancient name(s) & $\begin{array}{l}\text { Length } \\
\text { in } \mathbf{k m}\end{array}$ & $\begin{array}{l}\text { Ancient } \\
\text { name sur- } \\
\text { vived? }\end{array}$ \\
\hline 18 & $\begin{array}{l}\text { (French) Meuse / (Dutch) } \\
\text { Maas }^{34}\end{array}$ & (Lat.) Mosa & 930 & yes \\
\hline 19 & (Span.) Ebro ${ }^{35}$ & (Lat.) (H)iberus & 910 & yes \\
\hline 20 & $\begin{array}{l}\text { (Span.) Duero / (Portug.) } \\
\text { Douro }^{36}\end{array}$ & (Lat.) Durius & 900 & yes \\
\hline 21 & $\begin{array}{l}\text { (Czech.; Pol.) Odra / } \\
\text { (Germ.) Oder }\end{array}$ & (Greek) Syēbos ${ }^{37}$ & 870 & no \\
\hline 22 & $\begin{array}{l}\text { (Russ.) Kubán' / (Kabardi- } \\
\text { an) Psəž }\end{array}$ & (Greek) Hypanis $\sim$ Ouardanēs ${ }^{38}$ & 870 & (yes) \\
\hline 23 & $\begin{array}{l}\text { (Span.; Portug.) Guadia- } \\
n a^{39}\end{array}$ & (Lat.) Anas & 820 & yes \\
\hline 24 & $\begin{array}{l}\text { (French) Rhône / (Occitan.) } \\
\text { Ròse / (Germ.) Rotten }{ }^{40}\end{array}$ & (Lat.) Rhodanus & 810 & yes \\
\hline 25 & $\begin{array}{l}\text { (Pol.) Warta / (Germ.) } \\
\text { Warthe }\end{array}$ & - & 810 & - \\
\hline 26 & $\begin{array}{l}\text { (Russ.) Júžnyj Bug / (Ukra- } \\
\text { in.) Pivdénnyj Buh } \sim \text { Boh }^{42}\end{array}$ & (Greek) Hypanis & 810 & no \\
\hline
\end{tabular}

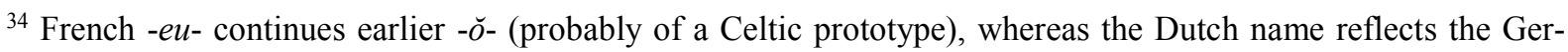
manic sound shift $\breve{o}>\breve{a}$ (cf. Krahe 1964: 96f.).

${ }^{35}$ The river originates at a place called Fontibre. It also gave the Iberian peninsula its name. On this river name $\Rightarrow$ below in section 9 .

${ }^{36}$ The river originates at a place called Duruelo de la Sierra. On this river name $\Rightarrow$ below in section 9 .

${ }^{37}$ Attested only by Ptolemaios. Although he even provides geographical coordinates, the identification of toponyms in the far North is difficult since his coordinates are distorted. I follow the identification by Reichert (2005: 280).

The modern name is first attested in the 9th century as Odagra (cf. Eichler 1981: 51; Georgiev 1966: 190). Both Volm's (1958: 8) identification of the river name with the Indo-European 'water'-term (Engl. water) and the connection with Avestan $a \delta u$ - 'channel' envisaged by Krahe (1964: 41) and Udolph (1990: 209f.) seem doubtful.

${ }^{38} \mathrm{I}$ assume that the form Hypanis is related to the modern (Russian) name despite the differing initial consonants. A Greek form Kōphèn, which matches the modern name more neatly, is attested in the 6th century AD (cf. Schramm 1973: 96).

${ }^{39}$ In the modern name, the Arabic noun wād $\bar{\imath}$ 'valley' was added to the original name.

${ }^{40}$ Old French Rosne. The German form is only in local use in the region of Switzerland where the river originates. On this river name $\Rightarrow$ below in section 9 . On the spelling with $R h$ - cf. $\Rightarrow$ Rhein.

${ }^{41}$ First attested in the 11th century as Vurta (cf. Udolph 1990: 282).

42 Old Russian Bog ; Byzantine Greek Bogou. When the vowel $b$ was dropped in Slavonic, $o$ of a preceding syllable underwent a compensatory lengthening which lead to $o$ (nowadays spoken $u$ ) in Polish and to $i$ (via $\ddot{u}$ ) in modern Standard Ukrainian. Traditional dialects of Northern Ukraine are closer to Polish in this respect and have $u o$ or $u$ here (cf. Shevelov 1979: 318). The river name was affected by this sound change and ended up with the dialectal reflex $u$ rather than the Standard Ukrainian reflex $i$. See Udolph (1983a) for further discussion and a list of early attestations. Udolph considers the name as related to the noun represented in German Bach $=$ Engl. dial. beck.

The earliest possible attestation of the modern name is Latin Vagosola $\sim$ Bagossola from the 6th/7th centuries (cf. Nepokupnyj et al. 1979: 422f.). If we accept this identification, it shows that medieval $o$ developed from an earlier $a$ (cf. $\Rightarrow$ Donau on this issue).

The name came to be homonymous with that of the $\Rightarrow$ Zapadnyj Bug which is at a distance of ca. $100 \mathrm{~km}$. This motivated the addition of discriminating adjectives on both names. A tributary of the Južnyj Bug is called Bužok, which is a diminutive formation.
} 


\begin{tabular}{|c|c|c|c|c|}
\hline No. & Modern name(s) & Ancient name(s) & $\begin{array}{l}\text { Length } \\
\text { in } \mathbf{k m}\end{array}$ & $\begin{array}{l}\text { Ancient } \\
\text { name sur- } \\
\text { vived? }\end{array}$ \\
\hline 27 & (Russ.) Sal & - & $800^{43}$ & - \\
\hline 28 & (French) Seine $e^{44}$ & (Lat.) Sequana & 780 & yes \\
\hline 29 & $\begin{array}{l}\text { (Roman.) Múreş / (Hun- } \\
\text { gar.) Maros }{ }^{45}\end{array}$ & (Greek) Marisos & 770 & yes \\
\hline 30 & $\begin{array}{l}\text { (Russ.) Príp'at' / (Ukrain.) } \\
\text { Prýp'jat' / (Polish) Prypeć }^{46}\end{array}$ & - & 770 & - \\
\hline 31 & $\begin{array}{l}\text { (Russ.) Západnyj Bug / } \\
\text { (Ukrain.) Záxidnyj Buh / } \\
\text { (Pol.) Bug }\end{array}$ & - & 770 & - \\
\hline 32 & $\begin{array}{l}\text { (Germ.) Drau / (Croat.; } \\
\text { Hungar.) Dráva }\end{array}$ & (Lat.) Dravus & 750 & yes \\
\hline 33 & (Russ.) Medvédica ${ }^{49}$ & - & 750 & - \\
\hline 34 & $\begin{array}{l}\text { (Germ.) Weser + (Germ.) } \\
\text { Werra }^{50}\end{array}$ & (Lat.) Visurgis & 740 & yes \\
\hline 35 & $\begin{array}{l}\text { (Russ.) Ps'ol / (Ukrain.) } \\
\text { Psel }^{51}\end{array}$ & - & 720 & - \\
\hline 36 & $\begin{array}{l}\text { (Roman.) Sirét / (Ukrain.) } \\
\text { Seret }^{52}\end{array}$ & (Greek) Hierasos / (Lat.) Gerasus & 710 & no \\
\hline 37 & (Russ.) Sejm ${ }^{53}$ & - & 700 & - \\
\hline No. & Modern name(s) & Ancient name(s) & $\begin{array}{l}\text { Length } \\
\text { in } \mathbf{~ k m}\end{array}$ & $\begin{array}{l}\text { Ancient } \\
\text { name sur- } \\
\text { vived? }\end{array}$ \\
\hline
\end{tabular}

\footnotetext{
${ }^{43}$ Including Džurak-Sal.

${ }^{44}$ Pronounced $/ s \varepsilon n /$; Old French Saine. We can probably postulate an early Romance form *sékna or *sákna, the development $-k C->-i C$ - being regular in French. The presence of $-q u$ - in the ancient spelling has always been puzzling because an earlier $/ k w /$ should have developed into ${ }^{*} p$ in the regional Celtic language (Gaulish). There are two ways out, either the assumption that $-q u$ - rendered something else than $/ k w /$ in this name, or that the region did not yet belong to the Gaulish territory when that sound change occurred. Jung (1970) opts for the first alternative.

${ }^{45}$ On this river name $\Rightarrow$ below in section 9 . On the phonetic development $\Rightarrow$ Donau.

${ }^{46}$ First attested in the 12th century as Pripetb (cf. Nepokupnyj et al. 1979: 446f.).

${ }^{47}$ All older sources already have the spelling Bug (cf. Fasmer 1964-87, I: 227). Cf. $\Rightarrow$ Južnyj Bug.

${ }^{48}$ On this river name $\Rightarrow$ below in section 9 .

${ }^{49}$ Interpretable as 'she-bear' in Russian.

${ }^{50}$ Today the upper river is called Werra and the lower river Weser. Both are split developments from a single older German name Wisera(ha). For similar names of other rivers cf. Krahe (1964: 50f.) and $\Rightarrow$ below in section 9.

${ }^{51}$ Genitive Psla. Various Old Russian spellings from the 12th century on (cf. Nepokupnyj et al. 1979: 451f.) which Fasmer (1964-87, III: 397) normalizes as *Pbsblb.

${ }^{52}$ See Duridanov (1999) and Schramm (1981: 351-353) on this river name. The modern name is first attested in 10 th century Greek sources as Sarat $\sim$ Seretos. No relationship with the ancient name is usually assumed, and I adopt this sceptical view here although a connection would become conceivable if the ancient forms should reflect a pronunciation such as *Žeras-. Herodotus cites a river Tiarantos which, somewhat less likely, may be identical with the Siret, too.

${ }^{53}$ Older spelling Semb (cf. Fasmer 1964-87, III: 600).
} 


\begin{tabular}{|c|c|c|c|c|}
\hline 38 & $\begin{array}{l}\text { (Russ.) Gorýn' / (Ukrain.) } \\
\text { Horýn }{ }^{154}\end{array}$ & - & 660 & - \\
\hline 39 & (Span.) Guadalquivir ${ }^{55}$ & (Lat.) Baetis & 660 & no \\
\hline 40 & (French) Garonne $e^{56}$ & (Lat.) Garumna $\sim$ Garunna & 650 & yes \\
\hline 41 & (Ital.) $P o^{57}$ & (Lat.) Padus $\sim$ Bodincus & 650 & yes \\
\hline 42 & (Russ.) Sožz8 & - & 650 & - \\
\hline 43 & (Roman.) Olt ${ }^{59}$ & (Lat.) Alutas & 620 & yes \\
\hline 44 & $\begin{array}{l}\text { (Russ.) Bereziná / (Be- } \\
\text { loruss.) B'arézina }\end{array}$ & - & 610 & - \\
\hline 45 & (Norweg.) Glomma & - & 600 & - \\
\hline 46 & (Finnish) Kemijoki ${ }^{61}$ & - & 550 & - \\
\hline 47 & $\begin{array}{l}\text { (French) Moselle / (Germ.) } \\
\text { Mosel }^{62}\end{array}$ & (Lat.) Mosella & 550 & yes \\
\hline 48 & $\begin{array}{l}\text { (Russ.) Inguléc / (Ukrain.) } \\
\text { Inhuléc }^{63}\end{array}$ & - & 550 & - \\
\hline 49 & (Swed.) Dalälven ${ }^{64}$ & - & $540^{65}$ & - \\
\hline 50 & (Russ.) Lóvat ${ }^{166}$ & - & 530 & - \\
\hline 51 & (Germ.) Main $^{67}$ & (Lat.) Moenus & 530 & yes \\
\hline 52 & (French) Marne 68 & (Lat.) Matrona & 520 & yes \\
\hline
\end{tabular}

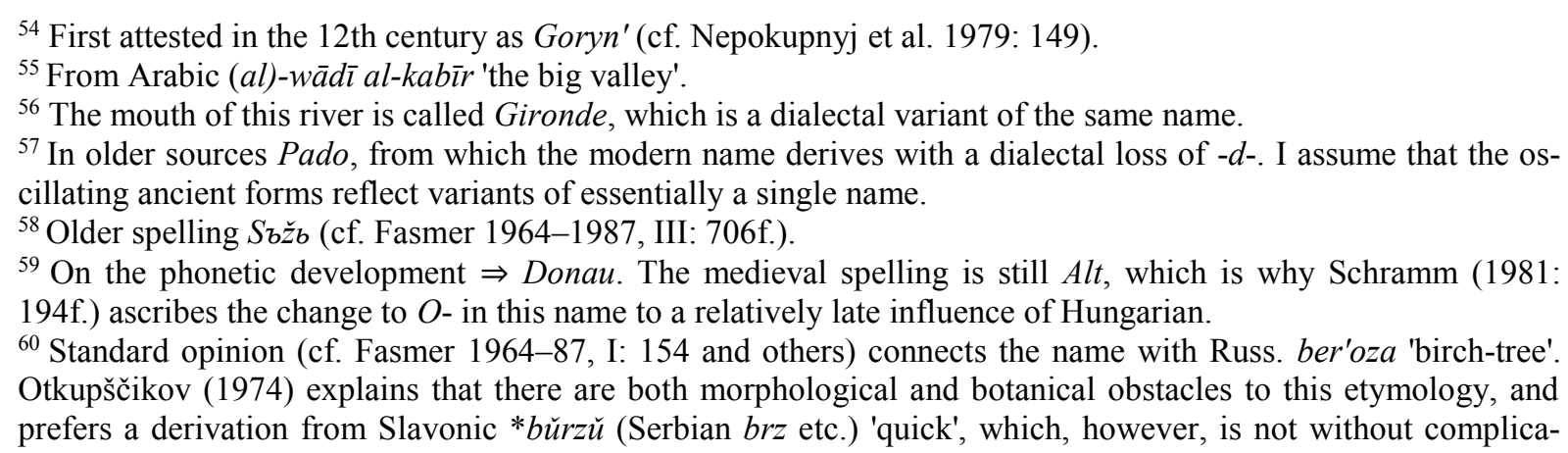
tions phonetically.

${ }^{61}$ Can be translated as 'field-river'.

${ }^{62}$ This name looks like a Latin diminutive (type ampulla) of the name of $\Rightarrow$ Meuse / Mosa. The Moselle is not a tributary of the Meuse, but both rivers are roughly parallel in their upper parts and approach to a minimal distance of about $10 \mathrm{~km}$. The Moselle in its turn has a tributary called Moselotte, which is thus a double diminutive. ${ }^{63}$ The name seems to be, apart from the Slavonic derivation suffix, identical with $\Rightarrow$ Ingul. The sources of both rivers are at a distance of about $25 \mathrm{~km}$.

${ }^{64}$ The name is interpretable as 'valley-river'.

${ }^{65}$ Including Västerdalälven.

${ }^{66}$ Old Russian form Lovotb (cf. Fasmer 1964-87, II: 508).

${ }^{67}$ In medieval sources Moyn Meun (German) / Mogus (Latin) (cf. Sperber 1970: 105-109). Modern ai for *oi is a dialectal feature. I believe that a derivative of the river name is found in the name of the city of Mainz / (Latin) Mogontiacum, which is located close to the mouth of the Main. Mogontiacum has traditionally been explained from the name of a Celtic god Mogons, who, however, is not otherwise known to have had any particular relationship to this place.

${ }^{68}$ The ancient name must evidently have been stressed Mátrona. There is also a French river Maronne, whose name might derive from *Matróna. It has long been noted that, specifically in the region of modern France, there are doublet toponyms deriving from prototypes that differ just in stress. For other examples among river names see $\Rightarrow$ Adour $\Rightarrow$ Aisne, $\Rightarrow$ Oise; examples from place names include Bourges $<$ Bitúriges vs. Berry $<$ Bituríges, 


\begin{tabular}{|c|c|c|c|c|}
\hline No. & Modern name(s) & Ancient name(s) & $\begin{array}{l}\text { Length } \\
\text { in } \mathbf{k m}\end{array}$ & $\begin{array}{l}\text { Ancient } \\
\text { name sur- } \\
\text { vived? }\end{array}$ \\
\hline 53 & $\begin{array}{l}\text { (Germ.) Inn / (Rhaeto- } \\
\text { Romance) } E n^{69}\end{array}$ & (Lat.) Aenus & 520 & yes \\
\hline 54 & $\begin{array}{l}\text { (Greek) Évros / (Bulgar.) } \\
\text { Maríca / (Turk.) Meriç }_{n^{70} r^{70}}\end{array}$ & (Greek) Ebros & 510 & no $^{71}$ \\
\hline 55 & $\begin{array}{l}\text { (Swed.) Torneälven / } \\
\text { (Finn.) Tornionjoki / } \\
\text { (Sami) Duortnoseatnu }\end{array}$ & - & 510 & - \\
\hline 56 & $\begin{array}{l}\text { (Russ.) Vilija } 73 \text { / (Lithuan.) } \\
\text { Neris }\end{array}$ & - & 510 & - \\
\hline 57 & (Span.) Júcar ${ }^{74}$ & (Lat.) Sucro & 500 & yes \\
\hline 58 & (Serb.) Mòrava & $\begin{array}{l}\text { (Greek) Margos } \sim \text { Bargos } \sim \\
\text { Brongos }\end{array}$ & $490^{76}$ & yes \\
\hline 59 & $\begin{array}{l}\text { (Russ.) Styr } \sim \text { Styr } r^{\prime} \\
\text { (Ukrain.) Styr }\end{array}$ & - & 490 & - \\
\hline 60 & (French) Dordogne 77 & (Lat.) Duranus & 480 & yes \\
\hline No. & Modern name(s) & Ancient name(s) & $\begin{array}{l}\text { Length } \\
\text { in } \mathbf{~ k m}\end{array}$ & $\begin{array}{l}\text { Ancient } \\
\text { name sur- } \\
\text { vived? }\end{array}$ \\
\hline
\end{tabular}

Nîmes < Némausus vs. Nemours < Nemáusus, Cosne < Cóndate vs. Condé < Condáte. The French and Breton names even of one and the same place may disagree as to their original stress positions, e. g. French Nantes $<$ Námnetes $=$ Breton Naoned $<$ Namnétes, French Rennes $<$ Rédones $=$ Breton Roazhon $<$ Redónes. A convincing explanation of this phenomenon is still lacking (see de Bernardo Stempel 1994: 16-18 for discussion).

${ }^{69}$ Since there is no known way of reconciling Latin ae-with German $i$-, it has been assumed that ae is here an aberrant spelling for *e. Some authors (e. g. Bichlmeier 2009: 32f.) derive this name from a root *pen- by assuming a transmission through Celtic, where $* p$ was lost.

${ }^{70}$ On this river name $\Rightarrow$ below in section 9. The ancient name has been preserved not only in Greek but also in the name of a Bulgarian village Poibrene situated on this river, as well as of a Bulgarian tributary Ibar (cf. Georgiev 1960: 26). The name Marica is first attested in a 12th century Arabic source (cf. Duridanov 1996: 222).

${ }^{71}$ I do not count the modern Greek name Évros here because, according to Schramm (1981: 290f.), a Greek name Maritza had already become predominant, when the ancient form Évros was artificially restituted in Greece as the name of this river.

${ }^{72}$ First attested in the 16th century as Tornö älff (cf. Wahlberg 2003: 322).

${ }^{73}$ The Lithuanian capital Vilnius, situated on this river, took its name from it.

${ }^{74} \mathrm{Cf}$. $\Rightarrow$ Tajo (on the phonetic aspects), $\Rightarrow$ Saône (on the suffix).

${ }^{75}$ On this river name $\Rightarrow$ below in section 9 . The modern name taken alone would seem comparable to the Bulgarian adjective mórav 'purple'. On the phonetic development $\Rightarrow$ Donau. Some details of the phonetic evolution remain obscure.

${ }^{76}$ Velika Morava + Zapadna Morava.

${ }^{77}$ The Dordogne is formed by a confluence of two torrents named Dore and Dogne. As the ancient form Duranus shows, the name cannot, however, be a compound from Dore + Dogne. Instead, this coincidence is either a result of secondary mutual assimilations of the three names or, as Rohlfs (1960: 11) says, the names Dore and Dogne only came into existence by splitting up the name Dordogne. Duranus was expanded to (later Latin) Doranonia (cf. $\Rightarrow$ Saône for the suffix), from which the modern name was formed by exchanging the first $-n-$ by $-d-$. On this river name $\Rightarrow$ also below in section 9 . 


\begin{tabular}{|c|c|c|c|c|}
\hline 61 & $\begin{array}{l}\text { (French) } \operatorname{Lot}^{78} / \text { (Occitan.) } \\
\text { Òlt }\end{array}$ & - & 480 & - \\
\hline 62 & $\begin{array}{l}\text { (Pol.) Narew / (Beloruss.) } \\
\text { Náraŭ }\end{array}$ & - & 480 & - \\
\hline 63 & $\begin{array}{l}\text { (Russ.) Oskól / (Ukrain.) } \\
\text { Oskíl } 79\end{array}$ & - & 470 & - \\
\hline 64 & (French) Saône $e^{80}$ & (Lat.) Arar $\sim$ Sauconna & 470 & (yes) \\
\hline 65 & $\begin{array}{l}\text { (Swed.) Umeälven / (Sami) } \\
\text { Ubmejeiednuo }^{81}\end{array}$ & - & 470 & - \\
\hline 66 & (Swed.) Angermanälven & - & 460 & - \\
\hline 67 & $\begin{array}{l}\text { (Swed.) Luleälven / (Sami) } \\
\text { Julevädno Lulejuädno }{ }^{82}\end{array}$ & - & 460 & - \\
\hline 68 & (Swed.) Klarälven ${ }^{83}$ & - & 460 & - \\
\hline 69 & (Russ.; Ukrain.) Vórskla ${ }^{84}$ & - & 460 & - \\
\hline 70 & (French) Doubs ${ }^{85}$ & (Lat.) Dubis & 450 & yes \\
\hline 71 & $\begin{array}{l}\text { (Latv.) Gauja / (Eston.) } \\
\text { Koiva jõgi }\end{array}$ & - & 450 & - \\
\hline 72 & $\begin{array}{l}\text { (Swed.) Kalixälven / (Sa- } \\
\text { mi) Gáláseatnu }\end{array}$ & - & 450 & - \\
\hline 73 & (Russ.) $M s t a^{87}$ & - & 450 & - \\
\hline 74 & $\begin{array}{l}\text { (Germ.) Mur / (Croat.; Slo- } \\
\text { vene) } \text { Mura }^{88}\end{array}$ & - & 450 & - \\
\hline
\end{tabular}

\footnotetext{
${ }^{78}$ Pronounced /lJt/. Medieval form Oltis (cf. Dauzat et al. 1978: 61). L- of the modern name must probably be a glued article, but the river is now called le Lot.

${ }^{79}$ First attested in the 12th century as Vbskolb (cf. Nepokupnyj et al. 1979: 404f.). On this river name $\Rightarrow$ below in section 9.

${ }^{80}$ Pronounced /son/; Old French Seonne. The latter part of this name could be (with Dauzat et al. 1978: 7; Jung 1970: 444) the Gaulish word onno 'river' recorded in a glossary from Late Antiquity (De nominibus gallicis, also called "Endlicher's glossary": onno = flumen), so that Sauc- would remain as the original name core. This Gaulish noun is probably identical with the element -on(no) described as a recurring suffix in river names by Rohlfs (1960: 27), found also in $\Rightarrow$ Júcar and possibly in $\Rightarrow$ Dordogne.

${ }^{81} \mathrm{Cf}$. the town of Umeå on the mouth of this river.

${ }^{82} \mathrm{Cf}$. the town of Lulea on the mouth of this river. The town is first attested in the 14th century as Lulu (Wahlberg 2003: 199).

${ }^{83}$ Interpretable as 'the clear river'.

${ }^{84}$ First attested in the 12th century as Vъrbskla (cf. Nepokupnyj et al. 1979: 123). Dobrodomov (1987) thinks that the name contains an Iranian word for 'white' (represented in Ossetic urs $\sim$ wors) as its first component. On this river name $\Rightarrow$ also below in section 9 .

${ }^{85}$ Pronounced $/ d u /$; the spelling with $-b$ - is historicizing. The name has been connected (e. g. by Dauzat et al. 1978: 40) with the common Celtic term for 'black' (Irish dubh, Breton and Welsh $d u$ ).

${ }^{86} \mathrm{Cf}$. the village of Kalix on the mouth of this river.

${ }^{87}$ Older spelling Mbsta Musta (cf. Pospelov 1998: 276f.). Pospelov explains the name from Finnish musta 'black'.

${ }^{88}$ First attested in the 9th century as (German) Muora (cf. Schramm 1981: 299; Udolph 1983b: 586). On this river name $\Rightarrow$ below in section 9 . There is a tributary Mürz which bears the same name together with a Slavonic diminutive suffix.
} 


\begin{tabular}{|c|c|c|c|c|}
\hline No. & Modern name(s) & Ancient name(s) & $\begin{array}{l}\text { Length } \\
\text { in } \mathbf{~ k m}\end{array}$ & $\begin{array}{l}\text { Ancient } \\
\text { name sur- } \\
\text { vived? }\end{array}$ \\
\hline 75 & $\begin{array}{l}\text { (Russ.) (Júžnaja) Sluč' / } \\
\text { (Ukrain.) Sluč }{ }^{89}\end{array}$ & - & 450 & - \\
\hline 76 & (Russ.) Voróna $a^{90}$ & - & 450 & - \\
\hline 77 & (Russ.) Íput' & - & 440 & - \\
\hline 78 & (Swed.) Ljusnan ${ }^{91}$ & - & 440 & - \\
\hline 79 & (Pol.) San / (Ukrain.) $S^{\prime} a n^{92}$ & - & 440 & - \\
\hline 80 & (Swed.) Indalsälven ${ }^{93}$ & - & 430 & - \\
\hline 81 & (Russ.) Velikaja ${ }^{94}$ & - & 430 & - \\
\hline 82 & $\begin{array}{l}\text { (Czech) Vltava / (Germ.) } \\
\text { Moldau }\end{array}$ & - & 430 & - \\
\hline 83 & (French) Allier ${ }^{96}$ & (Lat.) Elaver & 420 & yes \\
\hline 84 & (Roman.) Iálomiţa ${ }^{97}$ & - & 420 & - \\
\hline 85 & $\begin{array}{l}\text { (Russ.) Ptič' / (Beloruss.) } \\
\text { Pcič }\end{array}$ & - & 420 & - \\
\hline 86 & $\begin{array}{l}\text { (Ital.) Ádige / (Ladin) } \\
\text { Ádesc / (Germ.) Etsch }\end{array}$ & (Lat.) At(h)esis & 410 & \\
\hline 87 & $\begin{array}{l}\text { (Swed.) Piteälven / (Sami) } \\
\text { Byöhđameiednuo } \\
\text { Bihtámädno } 99\end{array}$ & - & 410 & - \\
\hline 88 & (Germ.) Saale ${ }^{100}$ & (Greek) Salas & 410 & yes \\
\hline
\end{tabular}

\footnotetext{
${ }^{89}$ On a possible etymology of this name see Udolph (1983b: 591f.).

${ }^{90}$ Homonymous with the Russian term for 'crow'.

${ }^{91}$ First attested in the 14th century as Lusn (cf. Wahlberg 2003: 195). Might seem to be related to Swed. ljus 'light'.

${ }^{92}$ Udolph (1990: 264-270) reconstructs the original form as *Senzb.

${ }^{93}$ First attested in the 14th century as Indal (cf. Wahlberg 2003: 150). An original and obscure name core *in was first expanded by dal 'valley' and then again by älv 'river'.

${ }^{94}$ Literally 'the big one'.

${ }^{95}$ Medieval spellings Wlitaua $\sim$ Wultha (cf. Schwarz 1961: 48). They suggest that the initial $V$ - of the Czech name is original and the similarity of the German name to other hydronyms (such as $\Rightarrow$ Mulde or a river Moldo$v a$ in Romania) is secondary. The latter river may have given its name to the state of Moldavia, unless Mann (1977: xii and 84) is right who proposes an Albanian etymology for the country name.

${ }^{96}$ Pronounced /alje/. A 9th century attestation Elarius (cf. Dauzat et al. 1978: 18) provides the link between the ancient and the modern forms.

${ }^{97}$ First attested in the 7th century as (Greek) Elibakia (cf. Schramm 1981: 257). Slavonic speakers seem to have reshaped the ending as *-ica, which was transcribed in Romanian as -itga (as also in $\Rightarrow$ Bistritga).

${ }^{98}$ In older sources Atexis $\sim$ Adizza $\sim$ Adice $\sim$ Etisa etc. (cf. Battisti 1962), whose spellings of the second consonant seem to reflect a spoken $/ \mathrm{J} /$ as still used in local Ladin. Modern Italian $-g-/ 3 /$ is of dialectal origin. There is a town Este (ancient Ateste) not far from this river, whose name is related.

${ }^{99} \mathrm{Cf}$. the town of Piteå on the mouth of this river. The town is first attested in the 14th century as Pitu (cf. Wahlberg 2003: 249).

${ }^{100}$ For similar names of other rivers cf. Krahe (1964: 49f.).
} 


\begin{tabular}{|c|c|c|c|c|}
\hline No. & Modern name(s) & Ancient name(s) & $\begin{array}{l}\text { Length } \\
\text { in } \mathbf{~ k m}\end{array}$ & $\begin{array}{l}\text { Ancient } \\
\text { name sur- } \\
\text { vived? }\end{array}$ \\
\hline 89 & $\begin{array}{l}\text { (Swed.) Skellefteälven / } \\
\text { (Sami) Seldutiednuo } \\
\text { Syöldateiednuo }\end{array}$ & - & 410 & - \\
\hline 90 & $\begin{array}{l}\text { (Bulgar.) Strúma / (Greek) } \\
\text { Strymónas }{ }^{102}\end{array}$ & (Greek) Strymōn & 410 & yes \\
\hline 91 & (Ital.) Tévere & (Lat.) Tiberis $\sim$ Albula & 410 & yes $^{103}$ \\
\hline 92 & (Swed.) Ljungan ${ }^{104}$ & - & 400 & - \\
\hline 93 & $\begin{array}{l}\text { (Roman.) Sómeş }{ }^{105} / \text { (Hun- } \\
\text { gar.) Szamos }\end{array}$ & (Lat.) Samus & $400^{106}$ & yes \\
\hline 94 & $\begin{array}{l}\text { (Germ.) Spree / (Sorbian) } \\
\text { Sprjewja }^{107}\end{array}$ & - & 400 & - \\
\hline 95 & $\begin{array}{l}\text { (Slovak) Váh / (Hungar.) } \\
\text { Vág }\end{array}$ & (Lat.) Cusus & 400 & no \\
\hline 96 & $\begin{array}{l}(\text { Pol.) Noteć / (Germ.) Net- } \\
z e^{109}\end{array}$ & - & 390 & - \\
\hline 97 & $\begin{array}{l}\text { (Engl.) Shannon / (Irish) } \\
\text { an tSionnain } 110\end{array}$ & (Greek) Sēnos & 390 & yes \\
\hline 98 & $\begin{array}{l}\text { (Bulgar.) Túndža / (Turk.) } \\
\text { Tunca }^{111}\end{array}$ & (Greek) Tonzos & 390 & yes \\
\hline 99 & $\begin{array}{l}\text { (Macedon.) Vardar } 112 / \\
\text { (Greek) Axiós }\end{array}$ & (Greek) Axios & 390 & yes \\
\hline
\end{tabular}

${ }^{101} \mathrm{Cf}$. the town of Skellefteå on the mouth of this river.

${ }^{102}$ This name is usually (e. g. Schramm 1981: 372) considered to be cognate with nouns such as Engl. stream and Latvian straume 'stream'. On this river name $\Rightarrow$ also below in section 9 .

${ }^{103}$ Tiberis was the common name of this river in the Latin of 2000 years ago. The Etruscan name is not directly attested, but allusions in ancient texts suggest that it must have been similar. By contrast, Albula has been reported as the early Latin name of the river (cf. Le Gall 1953: 50-53). I do not account for this latter name in my computation because its time distance from now significantly exceeds 2000 years.

${ }^{104}$ Pronounced /jenyan/. First attested in the 15th century as Ognar(-oos) (cf. Wahlberg 2003: 194). The initial $L j$ - of the modern form is a baroque spelling of the preposition $i$ 'in' which was fused with the original name.

${ }^{105}$ It has been suggested that the name is a derivation from the Slavonic root *som- 'catfish' (cf. Georgiev 1961: 93; Duridanov 1996: 222). On the phonetic development $\Rightarrow$ Donau. On this river name $\Rightarrow$ also below in section 9 .

${ }^{106}$ Including Someşul Mare.

${ }^{107}$ First attested in the 11th century as Sprewa (cf. Borchers 2006: 65f.).

${ }^{108}$ I follow the identification by Schramm (1981: 410f.). A derivative of the ancient name still survives in $K y$ suca, a tributary of the Váh.

${ }^{109}$ For details and considerations on the original name form see Udolph (1990: 185-193) and Krahe (1964: 28 and 47f.).

${ }^{110}$ The underlying root seems to be *sinn- (cf. Pokorny 1940: 127f.). Pokorny believes that the $-\bar{e}-$ of the Greek transcription is a spelling for $* i$.

${ }^{111}$ There is a small tributary Táža near the source of the Tundža. Both names are certainly related. Since Bulgarian $ə$ is the regular development of a Proto-Slavonic nasal vowel * $\tilde{o}$, Təža seems to be the authentic Bulgarian reflection of the ancient name, whereas Tundža must have been transmitted through a non-Slavonic language, probably Turkish (cf. Georgiev 1960: 28).

112 This name is first attested in the 11th century as (Greek) Bardar(e)ios (cf. Duridanov 1975: 32). 


\begin{tabular}{|c|c|c|c|c|}
\hline No. & Modern name(s) & Ancient name(s) & $\begin{array}{l}\text { Length } \\
\text { in } \mathbf{~ k m}\end{array}$ & $\begin{array}{l}\text { Ancient } \\
\text { name sur- } \\
\text { vived? }\end{array}$ \\
\hline 100 & (Russ.) Bit'úg ${ }^{113}$ & - & 380 & - \\
\hline 101 & (French) Charente & (Greek) Kanentelos ${ }^{114}$ & 380 & yes \\
\hline 102 & (French) Tarn & (Lat.) Tarnis & 380 & yes \\
\hline 103 & (French) Cher $^{115}$ & - & 370 & - \\
\hline 104 & (Germ.) Ems & (Lat.) Amisia / (Greek) Amasia & 370 & yes \\
\hline 105 & (Finn.) Iijoki ${ }^{116}$ & - & 370 & - \\
\hline 106 & (Bulgar.) Ískar & $\begin{array}{l}\text { (Greek) Oskios } \sim \text { Oiskos / (Lat.) } \\
\text { Oescus }\end{array}$ & 370 & yes \\
\hline 107 & (Germ.) Neckar ${ }^{117}$ & - & 370 & - \\
\hline 108 & $\begin{array}{l}\text { (Russ.) Téterev / (Ukrain.) } \\
\text { Téteriv }\end{array}$ & - & 370 & - \\
\hline 109 & $\begin{array}{l}\text { (French) Escaut / (Dutch) } \\
\text { Schelde }\end{array}$ & (Lat.) Scaldis & 360 & yes \\
\hline 110 & (Span.) Genil ${ }^{119}$ & (Lat.) Singilis & 360 & yes \\
\hline 111 & (Russ.) Ílovl'a & - & 360 & - \\
\hline 112 & $\begin{array}{l}\text { (Russ.) Súla / (Ukrain.) } \\
\text { Sulá }\end{array}$ & - & 360 & - \\
\hline 113 & $\begin{array}{l}\text { (Roman.) Timiş / (Serb.) } \\
\text { Tämiš / (Hungar.) Temes }{ }^{120}\end{array}$ & (Greek) Tibiskos $\sim(?)$ Tibisis & 360 & yes \\
\hline 114 & $\begin{array}{l}\text { (French) Vienne / (Occi- } \\
\operatorname{tan.)~Vinhana~}\end{array}$ & - & 360 & - \\
\hline 115 & (French) Aisne $e^{122}$ & (Lat.) Axona $\sim$ Axuenna & 350 & yes \\
\hline 116 & (Roman.) Árgeşs ${ }^{123}$ & (Greek) Ordēssos & 350 & yes \\
\hline
\end{tabular}

\footnotetext{
${ }^{113}$ First attested in the 14th century as Bet'uk (cf. Pospelov 1998: 69).

${ }^{114}$ A Latin attestation from a slightly later time is Carantonus (Ausonius, Mosella, 4th century).

${ }^{115}$ First attested in the 6th century as Cares (cf. Dauzat et al. 1978: 35). There is a village Chard near the source of this river, whose name is related.

${ }^{116} \mathrm{Cf}$. the village of Ii on the mouth of this river.

${ }^{117}$ First attested in Latin sources of the 4th century as Nicer $\sim$ Nigrus (cf. Krahe 1960).

${ }^{118}$ First attested in the 12th century as Teterevb (cf. Nepokupnyj et al. 1979: 562). The name is homonymous with a Russian term for a species of chicken.

${ }^{119}$ The Pre-Roman name underlying both the modern name and the Latin transcription seems to have been something like *šizill-. On the phonetic aspects cf. $\Rightarrow$ Tajo.

${ }^{120}$ Serbian $a$ can be the outcome of Proto-Slavonic $\breve{i}(b)$, which probably applies here. This suggests that the Greek spelling recorded a form *tĭbiš $(k)$-. Records with $-m$ - for the earlier $-b$ - are found from the 13 th century on (cf. Schramm 1981: 378). After this change, which may be due to folk-etymology, the name acquired a similarity to the Slavonic root *tim- 'dark'.

${ }^{121}$ First mentioned as Vingenna by Grégoire de Tours (6th century).

${ }^{122}$ Pronounced $/ \varepsilon n /$; the Latin attestation must be read Áxona. There is another French river Essonne, whose name seems to go back to *Axóna with a different accent position (cf. Dauzat et al. 1978: 18). Cf. $\Rightarrow$ Marne on this issue.
} 


\begin{tabular}{|c|c|c|c|c|}
\hline No. & Modern name(s) & Ancient name(s) & $\begin{array}{l}\text { Length } \\
\text { in } \mathbf{~ k m}\end{array}$ & $\begin{array}{l}\text { Ancient } \\
\text { name sur- } \\
\text { vived? }\end{array}$ \\
\hline 117 & (Serb.) Drina ${ }^{124}$ & (Greek) Dreinos / (Lat.) Drinus & 350 & yes \\
\hline 118 & (Russ.; Ukrain.) Ingúl $l^{125}$ & - & 350 & - \\
\hline 119 & $\begin{array}{l}\text { (Russ.) Lúga / (Votic) } \\
\text { Laugaz }^{126}\end{array}$ & - & 350 & - \\
\hline 120 & $\begin{array}{l}\text { (Czech; Slovak) Morava / } \\
\text { (German) March } \text { Mr7 }^{127}\end{array}$ & (Latin) Marus & 350 & yes \\
\hline 121 & (Norweg.) Numedalslågen & - & 350 & - \\
\hline 122 & $\begin{array}{l}\text { (Russ.) Orél' / (Ukrain.) } \\
\text { Oríl'128 }\end{array}$ & - & 350 & - \\
\hline 123 & (Russ.; Ukrain.) Ros ${ }^{\prime 129}$ & - & 350 & - \\
\hline 124 & $\begin{array}{l}\text { (Engl.) Severn }{ }^{130} /(\text { Welsh) } \\
\text { Hafren }\end{array}$ & (Lat.) Sabrina & 350 & yes \\
\hline 125 & (Engl.) Thames ${ }^{131}$ & (Lat.) Tamesa & 350 & yes \\
\hline 126 & (French) Oise $e^{132}$ & (Lat.) Isara & 340 & yes \\
\hline 127 & $\begin{array}{l}\text { (Russ.) Udáj / (Ukrain.) } \\
U^{\prime} d a j\end{array}$ & - & 340 & - \\
\hline 128 & (Lithuan.; Latv.) Venta ${ }^{133}$ & - & 340 & - \\
\hline 129 & (Russ.) Vorónež ${ }^{134}$ & - & 340 & - \\
\hline 130 & $\begin{array}{l}\text { (Alban.) Drin / (Serb.) } \\
\text { Drïm }^{135}\end{array}$ & (Greek) Drilōn & $330^{136}$ & yes \\
\hline
\end{tabular}

${ }^{123}$ If we take the ancient spelling seriously, we have to assume a sound change $/ d e />/ d z e /$ (= ge in the modern spelling) which is not regular in Romanian. Ionescu (1971) does accept the identification but nevertheless looks for Indo-European etymologies of the name based on a root*arg-. On this river name $\Rightarrow$ also below in section 9 . ${ }^{124}$ On this river name $\Rightarrow$ below in section 9 .

${ }^{125}$ For Fasmer (1964-87, II: 131), the name of this and several other Russian rivers is "doubtlessly" of Turkic origin, though he does not decide in favour of a specific etymology. On this river name $\Rightarrow$ below in section 9 . Cf. also $\Rightarrow$ Ingulec.

${ }^{126}$ Pospelov (1998: 247) compares the Estonian noun laugas 'pool'.

${ }^{127}$ Earliest German form Maraha (9th cent.; cf. Wiesinger 1994: 60), which shows that the German name is composed from Mar- (as attested in Latin) + -aha, a frequent element of Germanic river names (still a living word in Icelandic $a$ 'river', also in Gothic as ahwa 'river'). On this river name $\Rightarrow$ below in section 9 . On the phonetic development $\Rightarrow$ also Donau.

${ }^{128}$ First attested in a 12th century source as Erelb, the same source providing a "Russian" translation as Ugolb, lit. 'corner'. This may be explained as a folk-etymological association based on a Turkic language (cf. Fasmer 1964-87, III: 151).

${ }^{129}$ First attested in the 10th century as Rzsb (cf. Nepokupnyj et al. 1979: 475).

${ }^{130}$ Pronounced /'seva: $n /$. The change $s->h$ - is regular in Welsh.

${ }^{131}$ Pronounced /temz/; Old English Temes (cf. Ekwall 1928: 402-405, Förster 1941: 461-604). The modern spelling is artificial and seems to have been influenced by the Latin name.

${ }^{132}$ The loss of $-r$-, which became established during the 1st millennium (cf. Deroy/Mulon 1992: 351), cannot be explained from Romance and is perhaps to be ascribed to a peculiarity of the hypothetical local Celtic dialect. The Latin name must here be read Ísara, whereas the Latin name of $\Rightarrow$ Isère, which had the same spelling, must have been Isára. Cf. $\Rightarrow$ Marne on this issue. On this river name $\Rightarrow$ also below in section 9 .

${ }^{133} \mathrm{Cf}$. the town of Ventspils (Winda in earlier sources) on the mouth of this river.

${ }^{134}$ Similar name as $\Rightarrow$ Voróna. Both rivers are at a distance of about $150 \mathrm{~km}$. 


\begin{tabular}{|c|c|c|c|c|}
\hline No. & Modern name(s) & Ancient name(s) & $\begin{array}{l}\text { Length } \\
\text { in } \mathbf{k m}\end{array}$ & $\begin{array}{l}\text { Ancient } \\
\text { name sur- } \\
\text { vived? }\end{array}$ \\
\hline 131 & (Germ.) Havel ${ }^{137}$ & - & 330 & - \\
\hline 132 & $\begin{array}{l}\text { (Roman.) Jiu / (Hungar.) } \\
Z_{\text {Sill }}{ }^{138}\end{array}$ & - & 330 & - \\
\hline 133 & $\begin{array}{l}\text { (Hungar.) Körös / (Roman.) } \\
\text { Criş̧139 }\end{array}$ & - & $330^{140}$ & - \\
\hline 134 & (Russ.) Ščára & - & 330 & - \\
\hline 135 & $\begin{array}{l}\text { (Russ.) Svísloč' / (Be- } \\
\text { loruss.) Svíslačct11 }\end{array}$ & - & 330 & - \\
\hline 136 & $\begin{array}{l}\text { (French) Adour }{ }^{142} / \text { (Bas- }^{-} \\
\text {que) Aturri }\end{array}$ & (Lat.) Aturus & 320 & yes \\
\hline 137 & (Roman.) Buzắu 143 & - & 320 & - \\
\hline 138 & (Russ.) Čir & - & 320 & - \\
\hline 139 & (French) Durance $e^{144}$ & (Lat.) Druentia & 320 & yes \\
\hline 140 & $\begin{array}{l}\text { (Germ.) Eger / (Czech) } \\
\text { Ohře } e^{145}\end{array}$ & - & 320 & - \\
\hline 141 & (French) Loir ${ }^{146}$ & - & 320 & - \\
\hline 142 & (Pol.) Pilica ${ }^{147}$ & - & 320 & - \\
\hline 143 & (Russ.; Ukrain.) Samára ${ }^{148}$ & - & 320 & - \\
\hline 144 & (Span.) Segura ${ }^{149}$ & $\begin{array}{l}\text { (Lat.) Tader / (Greek) Taber } \sim \\
\text { Theodoros }\end{array}$ & 320 & no \\
\hline
\end{tabular}

135 The variation $l \sim n \sim m$ of the final consonant remains unexplained (cf. Schramm 1981: 235-237). On this river name $\Rightarrow$ below in section 9 .

${ }^{136}$ Including Drini i Bardhë.

${ }^{137}$ First attested in the 8th century as Habola (cf. Wauer 1999: 61).

${ }^{138}$ First attested in the 15th century as (Slavonic) Žil (cf. Schramm 1981: 349).

${ }^{139}$ First attested in the 6th century as (Latin) Grisia (cf. Schramm 1981: 279). The Hungarian name form splits the initial consonant cluster because such clusters were not accepted in earlier Hungarian.

${ }^{140}$ Including Crişul Alb.

${ }^{141}$ Older form Vislavica (cf. Pospelov 1998: 372).

${ }^{142}$ While Adour evidently derives from Atúr-, there is a town on this river named Aire-sur-l'Adour whose name (Aire) must go back to Atur-. Cf. $\Rightarrow$ Marne on this issue.

${ }^{143}$ First attested in the 4th century as (Greek) Mouseos (cf. Schramm 1981: 218f.) where M- might be a spelling for a heard $* b$-, a sound that did not exist in late antique Greek.

${ }^{144}$ On this river name $\Rightarrow$ below in section 9.

${ }^{145}$ First attested in the 9th century as Agara (cf. Borchers 2006: 19). For similar names of other rivers cf. Krahe (1964: 54f.).

${ }^{146}$ First attested in the 7th century as Ledus (cf. Dauzat et al. 1978: 59). Not to be confused with the river $\Rightarrow$ Loire, whose name has become homophonous in the modern language but differs in gender.

${ }^{147}$ Dialectally Pilca. Medieval spellings Pelza Pilcia (cf. Udolph 1990: 243-246).

148 This entry refers to the tributary to the $\Rightarrow$ Dnepr. There are other rivers so named, among them a $590 \mathrm{~km} l o n g$ tributary to the Volga, but cf. also $\Rightarrow$ Somme in France. The Samara referred to here is attested in Old Russian sources already under its present name (cf. Hengst 2001: 78).

${ }^{149}$ I assume that there is no connection to the ancient name forms, whose testimony for the second consonant is quite confused. Segura also repeatedly appears in Spanish village names. The name of the $\Rightarrow$ Segre looks similar as well. 


\begin{tabular}{|c|c|c|c|c|}
\hline No. & Modern name(s) & Ancient name(s) & $\begin{array}{l}\text { Length } \\
\text { in } \mathbf{~ k m}\end{array}$ & $\begin{array}{l}\text { Ancient } \\
\text { name sur- } \\
\text { vived? }\end{array}$ \\
\hline 145 & (Ital.) $A d d a$ & (Lat.) Addua & 310 & yes \\
\hline 146 & (Russ.) Buzulúk $k^{150}$ & - & 310 & - \\
\hline 147 & (Russ.) Jéja & - & 310 & - \\
\hline 148 & (Russ.) Kalitvá ${ }^{151}$ & - & 310 & - \\
\hline 149 & $\begin{array}{l}\text { (Span.) Miño / (Portug.) } \\
\text { Minho }\end{array}$ & (Lat.) Minius $\sim$ Bainis $^{152}$ & 310 & (yes) \\
\hline 150 & (Germ.) Mulde $e^{153}$ & - & $310^{154}$ & - \\
\hline 151 & (Bulgar.) Osəm ${ }^{155}$ & (Lat.) Asamus & 310 & yes \\
\hline 152 & (French) Sarthe $e^{156}$ & - & 310 & - \\
\hline 153 & $\begin{array}{l}\text { (Germ.) Thaya / (Czech) } \\
\text { Dyje }\end{array}$ & - & $310^{158}$ & - \\
\hline 154 & (Russ.; Ukrain.) Xoról $l^{159}$ & - & 310 & - \\
\hline 155 & (Greek) Aliákmonas & (Greek) Haliakmōn & 300 & yes \\
\hline 156 & $\begin{array}{l}\text { (Norweg.) Drammensvass- } \\
\text { draget }\end{array}$ & - & 300 & - \\
\hline 157 & $\begin{array}{l}\text { (Russ.) Drut' / (Beloruss.) } \\
\text { Druc }^{\prime 160}\end{array}$ & - & 300 & - \\
\hline 158 & (Slovak) Hron ${ }^{161}$ & (Greek) Granouas & 300 & yes \\
\hline 159 & (Germ.) Isar ${ }^{162}$ & (Greek) Isara & 300 & yes \\
\hline 160 & $\begin{array}{l}\text { (Croat.) Küpa / (Sloven.) } \\
\text { Kolpa }\end{array}$ & (Lat.) Colapis & 300 & yes \\
\hline 161 & $\begin{array}{l}\text { (Finn.) Ounasjoki / (Sami) } \\
\text { Ovnnesjohka }\end{array}$ & - & 300 & - \\
\hline 162 & $\begin{array}{l}\text { (Lithuan.) Šešupè / (Pol.) } \\
\text { Szeszupa / (Russ.) Šešúpe / } \\
\text { (Germ.) Scheschuppe }\end{array}$ & - & 300 & - \\
\hline
\end{tabular}

\footnotetext{
${ }^{150}$ Pospelov (1998: 83) derives the name from a Turkic word for 'frozen'.

${ }^{151}$ First attested in the 16th century, already under its present name (cf. Otin 1989).

${ }^{152}$ It is unclear whether Bainis is a variant of Minius or an essentially different name of the same river. I decide for the second option here.

${ }^{153}$ First attested in the 10th century as Milda (cf. Borchers 2006: 40f.). Cf. also $\Rightarrow$ Vltava.

${ }^{154}$ Including Zwickauer Mulde.

${ }^{155}$ On the phonetic development $\Rightarrow$ Donau.

${ }^{156}$ First attested in the 9th century as Sarta (cf. Dauzat et al. 1978: 82).

${ }^{157}$ Oldest attestations Dya $\sim$ Dia $\sim$ Tigia (ca. 1100 AD; cf. Wiesinger 1994: 66). The modern German form with diphthongization $* \bar{\imath}>$ ai.

${ }^{158}$ Including Deutsche Thaya.

${ }^{159}$ First attested in the 12th century as Xorolb (cf. Fasmer 1964-87, IV: 265f.).

${ }^{160}$ On this river name $\Rightarrow$ below in section 9 .

${ }^{161}$ On the phonetic development $\Rightarrow$ Donau.

162 On this river name $\Rightarrow$ below in section 9 .

163 -upe is the Lithuanian word for 'river'.
} 


\begin{tabular}{|c|c|c|c|c|}
\hline No. & Modern name(s) & Ancient name(s) & $\begin{array}{l}\text { Length } \\
\text { in } \mathbf{k m}\end{array}$ & $\begin{array}{l}\text { Ancient } \\
\text { name sur- } \\
\text { vived? }\end{array}$ \\
\hline 163 & (Engl.) Trent ${ }^{164}$ & (Lat.) Trisantona & 300 & yes \\
\hline 164 & (Pol.) Wieprz ${ }^{165}$ & - & 300 & - \\
\hline 165 & (Germ.) Aare & (Lat.) Arura ${ }^{166}$ & 290 & yes \\
\hline 166 & (Roman.) Bârlád & - & 290 & - \\
\hline 167 & (Roman.) Bístriţa ${ }^{167}$ & - & 290 & - \\
\hline 168 & (Pol.; Slovak) Dunajec ${ }^{168}$ & - & $290^{169}$ & - \\
\hline 169 & (Span.) Esla ${ }^{170}$ & (Lat.) Astura & 290 & yes \\
\hline 170 & $\begin{array}{l}\text { (Slovak) Hornád / (Hung.) } \\
\text { Hernád }\end{array}$ & - & 290 & - \\
\hline 171 & (French) Isère ${ }^{171}$ & (Lat.) Isara & 290 & yes \\
\hline 172 & $\begin{array}{l}\text { (Bulgar.) Jántra, upper part } \\
\text { called Étər }\end{array}$ & $\begin{array}{l}\text { (Greek) Athrys / (Lat.) Ieterus } \\
\text { Iatrus }\end{array}$ & 290 & yes \\
\hline 173 & $\begin{array}{l}\text { (Pol.) Lyna / (Russ.) Láwa / } \\
\text { (Germ.) Alle / (Lithuan.) } \\
\text { Alna }^{173}\end{array}$ & - & 290 & - \\
\hline 174 & $\begin{array}{l}\text { (Roman.) Răut / (Ukrain.) } \\
\text { Reút }^{174}\end{array}$ & - & 290 & - \\
\hline 175 & (Russ.) Savalá & - & 290 & - \\
\hline 176 & (Russ.; Ukrain.) Úbort' & - & 290 & - \\
\hline 177 & $\begin{array}{l}\text { (Pol.) Bóbr / (Czech) Bobr } \\
/ \text { (Germ.) Bober }{ }^{175}\end{array}$ & - & 280 & - \\
\hline
\end{tabular}

${ }^{164}$ Old English Treenta Treonta (cf. Ekwall 1928: 415-418). The loss of -s- is a regular sound development of early British Celtic.

${ }^{165}$ This is also a Polish noun for 'castrated pig'.

166 Zinsli 1976, vol. I: 39.

${ }^{167}$ Contains the Slavonic suffix -ica like $\Rightarrow$ Ialomita. Bystrica (and variants) appears dozens of times as a river name in the Slavonic area. This name has been studied by Udolph (1981/83). In some languages, e. g. Slovak, bystrica is still a common noun for 'steep mountain torrent'. In agreement with that, Bystrica's are typically found in mountain areas, which also fits the Bistriţa at least in its upper part (the Bistriţa originates at 1650 metres above sea level in the Carpathian mountains). The underlying Slavonic root *bystr- means 'clear' in some languages (Serbian bistar, Bulgarian bistar) and 'quick' in others (Russian býstryj). While this is one of the most probable candidates in the present list for a recent name invention, the general question remains whether such a semantically transparent name is original or came into existence by a folk-etymological reinterpretation of an earlier name which just happened to be similar in sound. Cf. also $\Rightarrow$ below in section 9 .

${ }^{168}$ On this river name $\Rightarrow$ below in section 9.

${ }^{169}$ Including Czarny Dunajec.

${ }^{170}$ The ancient name was evidently stressed Ástura. The medieval form Estola illustrates the path of phonetic development. On the phonetic aspects cf. $\Rightarrow$ Tajo.

The ancient name appears to contain the Basque noun ur 'water' (cf. Laso 1966: 299). It also survives in the names of the town Astorga (ancient Astúrica), situated near a tributary of the Esla, and of the province Asturia.

${ }^{171}$ On this river name see $\Rightarrow$ Oise and $\Rightarrow$ below in section 9 .

${ }^{172}$ The $-n$ - must be intrusive; $j a \sim e$ is a known inner-Bulgarian dialectal alternation.

${ }^{173}$ First attested in the 13th century as Alna (cf. Biolik 1996: 113). The name of the town Olsztyn / Allenstein, situated on this river, is related.

${ }^{174}$ Fasmer (1964-87, III: 476) speculates that this name might derive from an earlier *Revõt. 


\begin{tabular}{|c|c|c|c|c|}
\hline No. & Modern name(s) & Ancient name(s) & $\begin{array}{l}\text { Length } \\
\text { in } \mathbf{k m}\end{array}$ & $\begin{array}{l}\text { Ancient } \\
\text { name sur- } \\
\text { vived? }\end{array}$ \\
\hline 178 & (Turk.) Ergene & (Greek) Agrianēs & 280 & yes \\
\hline 179 & (Serb.) İbar ${ }^{176}$ & - & 280 & - \\
\hline 180 & $\begin{array}{l}\text { (Roman.) Jijia / (Ukrain.) } \\
\check{Z} y z ̌ i j a^{177}\end{array}$ & - & 280 & - \\
\hline 181 & (Finn.) Kitinen ${ }^{178}$ & - & 280 & - \\
\hline 182 & (Germ.) Leine ${ }^{179}$ & - & 280 & - \\
\hline 183 & (Ital.) Oglio & (Lat.) Ollius & 280 & yes \\
\hline 184 & (Span.) Pisuerga & (Lat.) Pisoraca & 280 & yes \\
\hline 185 & (Russ.) $P l^{\prime} u ́ s s a^{180}$ & - & 280 & - \\
\hline 186 & $\begin{array}{l}\text { (Germ.) Raab / (Hungar.) } \\
\text { Rába }\end{array}$ & (Lat.) Arrabo & 280 & yes \\
\hline 187 & $\begin{array}{l}\text { (Russ.) Súna / (Finn.) Su- } \\
\text { unujoki }\end{array}$ & - & 280 & - \\
\hline 188 & (Ital.) Tànaro & (Lat.) Tanarus & 280 & yes \\
\hline 189 & (Span.) Tormes ${ }^{181}$ & - & 280 & - \\
\hline 190 & (Span.) Turia ${ }^{182}$ & (Lat.) Turia & 280 & yes \\
\hline 191 & $\begin{array}{l}\text { (Bulgar.) Arda / (Greek) } \\
\text { Ardas }\end{array}$ & (Greek) Artiskos & 270 & yes \\
\hline 192 & (Croat.) Bösna ${ }^{183}$ & (Lat.) Bathinus & 270 & yes \\
\hline 193 & (Russ.) Oját' & - & 270 & - \\
\hline 194 & (Russ.) Polá & - & 270 & - \\
\hline 195 & $\begin{array}{l}\text { (Span.) Segre / (French) } \\
\text { Sègre }^{184}\end{array}$ & (Lat.) Sicoris & 270 & yes \\
\hline 196 & $\begin{array}{l}\text { (Alban.) Vjosë / (Greek) } \\
\text { Aôos }^{185}\end{array}$ & (Greek) Aōos $\sim$ Aias $\sim$ Auos & 270 & yes \\
\hline
\end{tabular}

175 The Polish and Czech names would be translatable as 'beaver'.

${ }^{176}$ Medieval spellings Ybro Ibru (cf. Schramm 1981: 257). On this river name $\Rightarrow$ below in section 9.

${ }^{177}$ Attested from the 15th century in various variants such as Žežia, Dzižia etc. (cf. Ciocan-Ivănescu/Ivănescu 1969). Ciocan-Ivănescu and Ivănescu assume that the form with $-e$ - is original and $-i$ - is due to a Ukrainian sound change.

${ }^{178}$ Genitive Kitisen.

${ }^{179}$ Medieval spellings Lagina $\sim$ Leyna $\sim$ Loina (cf. Kettner 1973: 70f.). It is not clear whether $-g$ - is authentic or only a Latin spelling for $/ j /$.

${ }^{180}$ First attested in the 16th century as Pl'usa (cf. Pospelov 1998: 333).

${ }^{181}$ Originates at a place called Prado Tormejón.

182 Originates in the town of Teruel, whose name is related.

${ }^{183}$ For the identification see Schramm (1981: 214f.) and Talbert (2000, vol. I: 289). Medieval Latin sources write Bosina (Schramm). It seems that the ancient -th- transliterated a fricative $/ \theta /$ of the local language (Illyrian?), which Slavonic speakers later substituted by $/ s /$. On the phonetic development $\Rightarrow$ also Donau.

${ }^{184}$ On the name cf. also $\Rightarrow$ Segura.

${ }^{185}$ Medieval spellings include Biusa, Vaiussa and (Greek) Boousa (cf. Schramm 1981: 406). We can probably reconstruct the original name as approximately ${ }^{*}$ Wajo $s-o s / \bar{a}$, from which $w-, j-$ and $-s$ - were regularly lost in 


\begin{tabular}{|c|c|c|c|c|}
\hline No. & Modern name(s) & Ancient name(s) & $\begin{array}{l}\text { Length } \\
\text { in } \mathbf{k m}\end{array}$ & $\begin{array}{l}\text { Ancient } \\
\text { name sur- } \\
\text { vived? }\end{array}$ \\
\hline 197 & (Germ.) Aller ${ }^{186}$ & - & 260 & - \\
\hline 198 & $\begin{array}{l}\text { (Roman.) Bega / (Serb.) } \\
\text { Bègej } 187\end{array}$ & - & 260 & - \\
\hline 199 & $\begin{array}{l}\text { (Russ.) Bésed' / (Beloruss.) } \\
\text { Bésedz' }\end{array}$ & - & 260 & - \\
\hline 200 & (Germ.) $\operatorname{Lech}^{188}$ & (Greek) Likias & 260 & yes \\
\hline 201 & (Russ.) $M e \check{z} a^{189}$ & - & 260 & - \\
\hline 202 & (Russ.; Ukrain.) Miús & - & 260 & - \\
\hline 203 & $\begin{array}{l}\text { (Russ.) } S^{\prime} a s^{\prime} / \text { (Vepsian) } \\
\text { Sääs }\end{array}$ & - & 260 & - \\
\hline 204 & (French) Somme & $($ Lat. $) *$ Samara $^{190}$ & 260 & yes \\
\hline 205 & $\begin{array}{l}\text { (Russ.; Ukrain.) Už / (Slo- } \\
\text { vak) Uh / (Hung.) Ung }\end{array}$ & - & 260 & - \\
\hline 206 & $\begin{array}{l}\text { (Germ.) Weiße Elster / } \\
\text { (Czech) Bílý Halštrov }{ }^{192}\end{array}$ & - & 260 & - \\
\hline 207 & (Germ.) Enns ${ }^{193}$ & - & 250 & - \\
\hline 208 & (Bulgar.) Kámčija ${ }^{194}$ & (Greek) Panysos / (Lat.) Pannysis & 250 & no \\
\hline 209 & $\begin{array}{l}\text { (Pol.) Nysa Łużycka / } \\
\text { (Germ.) Lausitzer Neiße / } \\
\text { (Czech) Lužická Nisa }\end{array}$ & - & 250 & - \\
\hline 210 & $\begin{array}{l}\text { (Norweg.) Skiensvassdra- } \\
\text { get }\end{array}$ & - & 250 & - \\
\hline
\end{tabular}

Table 1: Data table.

Greek. The Albanian name must have been transmitted by a language in which all three consonants remained intact.

${ }^{186}$ First attested in the 9th century as Halera (cf. Borchers 2005: 3). H- (in a Latin context) is probably not authentic here since most other medieval sources write Alera.

${ }^{187}$ First attested in the 13th century as Beguey (cf. Schramm 1981: 207).

${ }^{188}$ Various suggestions for etymologizing this name are discussed by Bichlmeier (2009: 43-46).

189 This is also a Russian word for 'borderline'.

190 Reconstructed from Samarobriva, the ancient name of the town of Amiens situated on this river (briva $=$ Gaulish 'bridge'). The first attestations of the river itself appear in Late Antiquity as Sambra $\sim$ Somena $\sim$ Sumina $\sim$ Sumna. See Deroy and Mulon (1992: 452). On the phonetic development $\Rightarrow$ also Donau.

${ }^{191}$ The Russian name appears to mean 'adder'. There is a town Užgorod on this river which is attested in the 10th century as Ungvar (cf. Pospelov 1998: 430; vár = Hungarian 'castle'). We can reconstruct an older Slavonic form * og which experienced the regular Slavonic sound change $\tilde{o}>u$. In the Hungarian name, the original nasal was preserved.

${ }^{192}$ First attested in the 11th century as Elstra Alestra (cf. Borchers 2006: 70). There is also a Schwarze Elster at $70 \mathrm{~km}$ distance which was homonymous already in medieval times (cf. ibid.: 65). On this river name $\Rightarrow$ below in section 9.

${ }^{193}$ First attested in the 4th century as (Latin) Anisus, later as En(i)sa (cf. Wiesinger 1994: 62).

194 This name has been explained from Turkish by Georgiev (1960: 32f., < gemici 'sailor') and by Schramm (1981: 268, folk-etymological derivation from kamçı 'whip').

${ }^{195}$ There are several other rivers called Nysa / Neiße in this region. 


\section{$6 \quad$ Alphabetic index}

The following alphabetic index contains all rivers of the above list in alphabetical sorting.

\begin{tabular}{|c|c|c|c|c|c|c|c|c|c|}
\hline Name & No. & Durance & 139 & Koiva jõgi & 71 & Oise & 126 & Spree & 94 \\
\hline Aare & 165 & $\begin{array}{l}\text { Dvina, } \\
\text { Zapadnaja }\end{array}$ & 11 & Kolpa & 160 & Ojat' & 193 & Struma & 90 \\
\hline Adda & 145 & Dyje & 153 & Körös & 133 & Olt & 43 & Styr & 59 \\
\hline Adige & 86 & Ebro & 19 & Kuban' & 22 & Orel' $^{\prime}$ & 122 & Sula & 112 \\
\hline Adour & 136 & Eger & 140 & Кира & 160 & Osam & 151 & Suna & 187 \\
\hline Aisne & 115 & Elbe & 7 & Labe & 7 & Oskol & 63 & Svisloč & 135 \\
\hline Aliákmonas & 155 & Elster & 206 & Lech & 200 & Ounasjoki & 161 & Szamos & 93 \\
\hline Aller & 197 & Ems & 104 & Leine & 182 & Pilica & 142 & Tajo & 10 \\
\hline Allier & 83 & Enns & 207 & Ljungan & 92 & Pisuerga & 184 & Tamiš & 113 \\
\hline $\begin{array}{l}\text { Ångerman- } \\
\text { älven }\end{array}$ & 66 & Ergene & 178 & Ljusnan & 78 & Piteälven & 87 & Tanaro & 188 \\
\hline Aôos & 196 & Escaut & 109 & Loir & 141 & Pl'ussa & 185 & Tarn & 102 \\
\hline Arda & 191 & Esla & 169 & Loire & 12 & Po & 41 & Teterev & 108 \\
\hline Argeş & 116 & Etsch & 86 & Lot & 61 & Polá & 194 & Tevere & 91 \\
\hline Axiós & 99 & Évros & 54 & Lovat' & 50 & Prip'at' & 30 & Thames & 125 \\
\hline Bârlad & 166 & Garonne & 40 & Luga & 119 & Prut & 16 & Thaya & 153 \\
\hline Bega & 198 & Gauja & 71 & Luleälven & 67 & Ps'ol & 35 & Timiş & 113 \\
\hline Berezina & 44 & Genil & 110 & Eyna & 173 & Ptič' & 85 & Tisza & 15 \\
\hline Besed' & 199 & Glomma & 45 & Maas & 18 & $R a a b$ & 186 & Tormes & 189 \\
\hline Bistriţa & 167 & Goryn' & 38 & Main & 51 & Răut & 174 & Torneälven & 55 \\
\hline Bit'ug & 100 & Guadalquivir & 39 & March & 120 & Rhein & 5 & Trent & 163 \\
\hline Bóbr & 177 & Guadiana & 23 & Marica & 54 & Rhône & 24 & Tundža & 98 \\
\hline Bosna & 192 & Havel & 131 & Marne & 52 & $\operatorname{Ros}^{\prime}$ & 123 & Turia & 190 \\
\hline Bug, Južnyj & 26 & Hornád & 170 & Medvedica & 33 & $S^{\prime} a s^{\prime}$ & 203 & Tysa & 15 \\
\hline $\begin{array}{l}\text { Bug, } \\
\text { Zapadnyj }\end{array}$ & 31 & Hron & 158 & Memel & 17 & Saale & 88 & Ubort' & 176 \\
\hline Buzău & 137 & Ialomiţa & 84 & Meuse & 18 & Sal & 27 & Udaj & 127 \\
\hline Buzuluk & 146 & Ibar & 179 & Meža & 201 & Samara & 143 & Umeälven & 65 \\
\hline Charente & 101 & Iijoki & 105 & Miño & 149 & San & 79 & $U \check{z}$ & 205 \\
\hline Cher & 103 & Ilovl'a & 111 & Mius & 202 & Saône & 64 & Váh & 95 \\
\hline Čir & 138 & Indalsälven & 80 & Moldau & 82 & Sarthe & 152 & Vardar & 99 \\
\hline Criş & 133 & Ingul & 118 & Morava & 58 & Sava & 13 & Velikaja & 81 \\
\hline Dalälven & 49 & Ingulec & 48 & Morava & 120 & Savala & 175 & Venta & 128 \\
\hline Desna & 6 & Inn & 53 & Moselle & 47 & Ščara & 134 & Vienne & 114 \\
\hline
\end{tabular}




\begin{tabular}{|c|c|c|c|c|c|c|c|c|c|}
\hline Dnepr & 2 & Iput' & 77 & Msta & 73 & Schelde & 109 & Vilija & 56 \\
\hline Dnestr & 4 & Isar & 159 & Mulde & 150 & Segre & 195 & Vjosë & 196 \\
\hline Don & 3 & Isère & 171 & Mur & 74 & Segura & 144 & Vltava & 82 \\
\hline Donau & 1 & Iskar & 106 & Mureş & 29 & Seine & 28 & Vorona & 76 \\
\hline $\begin{array}{l}\text { Donec, } \\
\text { Severskij }\end{array}$ & 9 & Jantra & 172 & Narew & 62 & Sejm & 37 & Voronež & 129 \\
\hline Dordogne & 60 & Jeja & 147 & Neckar & 107 & Šešupe & 162 & Vorskla & 69 \\
\hline Doubs & 70 & Jijia & 180 & $\begin{array}{l}\text { Neiße, } \\
\text { Lausitzer }\end{array}$ & 209 & Severn & 124 & Warta & 25 \\
\hline $\begin{array}{l}\text { Drammens- } \\
\text { vassdraget }\end{array}$ & 156 & Jiu & 132 & Neman & 17 & Shannon & 97 & Werra & 34 \\
\hline Drau & 32 & Jucar & 57 & Neris & 56 & Siret & 36 & Weser & 34 \\
\hline Drin & 130 & Kalitva & 148 & Noteć & 96 & $\begin{array}{l}\text { Skellefteäl- } \\
\text { ven }\end{array}$ & 89 & Wieprz & 164 \\
\hline Drina & 117 & Kalixälven & 72 & $\begin{array}{l}\text { Nume- } \\
\text { dalslågen }\end{array}$ & 121 & $\begin{array}{l}\text { Skiensvass- } \\
\text { draget }\end{array}$ & 210 & Wista & 8 \\
\hline Drut' & 157 & Kamčija & 208 & $\begin{array}{l}\text { Nysa } \\
\text { Łużycka }\end{array}$ & 209 & Sluč' & 75 & Xop'or & 14 \\
\hline Duero & 20 & Kemijoki & 46 & Odra & 21 & Someş & 93 & Xorol & 154 \\
\hline Dunajec & 168 & Kitinen & 181 & Oglio & 183 & Somme & 204 & Zsil & 132 \\
\hline Dunav & 1 & Klarälven & 68 & Ohře & 140 & Sož & 42 & Žyžyja & 180 \\
\hline
\end{tabular}

Table 2: Alphabetic index of river names.

\section{7 (Apparently) transparent river names}

Numerous river names are or, better, seem to be semantically transparent. Aside from the fact that they often contain a component simply meaning 'river' (see the next section), I wish to point out three semantic fields that appear to be particularly recurrent in river names:

- The names of a lot of rivers in Europe and world-wide are interpretable as colour terms, most frequently in the senses of 'white' 'clear', 'black' 'dark', or 'red'. Among all rivers whose names are (or seem to be) semantically transparent, this type is the most common one. The above list contains the examples $\Rightarrow$ Bistriţa, $\Rightarrow$ Doubs, $\Rightarrow E l$ be, $\Rightarrow$ Klarälven, $\Rightarrow$ Ljusnan, $\Rightarrow$ Morava $\Rightarrow$ Msta $\Rightarrow$ Timiş, and $\Rightarrow$ Vorskla. Numerous Russian rivers bear the names Bélaja 'the white one', Č́rnaja 'the black one' or Krásnaja 'the red one'. Several German torrents are called Weißenbach / Weißwasser or Schwarzenbach / Schwarzwasser. Other European river names of this type include Alfambra (Spain, from Arabic *al-hamrā 'the red one'), Crna Reka (Macedonia), Eau Rouge (Belgium), Glan (Germany, Austria) Glane (France) Glâne (Switzerland) Glen (Britain) (compared by Krahe 1954: 129f. with a Celtic term for 'clean, clear' ${ }^{196}$ ),

\footnotetext{
${ }^{196}$ Irish, Breton glan = Welsh glân 'clean, clear', to which also the English adjective clean might be related. However, some or all of these names are probably better explained from another Celtic word, namely Irish gleann = Welsh glyn 'valley', borrowed into Scottish English as glen .
} 
Kirsna (Lithuania, associable to a Balto-Slavic root for 'black'), Lauterbach $\sim$ Lutter (Germany, lauter is an obsolete term for 'clear'), Mavronéri (Greece), Nera (Italy), Rio Tinto (Spain), Röthenbach (Germany), Tamnava (Serbia) and Zwarte Water (Netherlands), to cite only a few examples. In cases such as Argentina ('silver', Italy) or Zlati$c a$ ('golden', Serbia), it could be disputed whether the name refers to the visual appearance of the river or to prehistorical metal findings in these locations.

The colour motive is very common on other continents as well. Rohlfs (1960: 5) states that the European colonists of America often resorted to colour terms when coining names for newly encountered rivers. We so find numerous rivers in Latin America bearing the Spanish names Río Blanco or Río Negro, as well as several Rio Verde in Brazil. Well-known rivers in the USA include the Colorado River, Green River,

Orange River ${ }^{197}$, Red River and Yellowstone River. Two of the largest Turkish rivers are called Kızılırmak 'red river' and Yeşilırmak 'green river', there is also a Bozçay 'gray torrent', and two Anatolian rivers had the name Xanthos 'yellow' in Ancient Greek. Two major rivers of China are the Huáng Hé 'yellow river' and the Hóng Hé 'red river'. One of the largest rivers of Africa is the Niger ${ }^{198}$, from which the states of Niger and Nigeria took their names. See further the lists under the entries "White River", "Black River", "Red River" etc. in the English Wikipedia.

It is very often the case, but as it seems only in the Eastern half of Europe, that two sources of one river or two neighboured rivers are opposed to each other by the attributes 'white' and 'black'. Examples include Crişul Alb - Crişul Negru (Romania), Drini i Bardhë - Drini i Zi (Albania), Biaty Dunajec - Czarny Dunajec (Poland), Weiße Elster - Schwarze Elster (Germany), Beli Iskar - Černi Iskar (Bulgaria), Beli Timok Crni Timok (Serbia), Bila Tysa - Čorna Tysa (Ukraine), Biała Wisetka - Czarna Wisetka (Poland). Oppositions involving other colour pairs are found in Weißer Main - Roter Main (Germany) and in the African rivers White Nile - Blue Nile.

It may be surprising to find that terms for 'blue' seem to be somewhat less popular for the purpose of river naming, but examples with this colour term are attested as well: Blau (Germany, near the town of Blaubeuren), Blue Nile, several Blue Rivers in the USA, Glaúkos (Greece), and possibly the Italian river Piave (ancient Plavis), if this name should be related to Croatian plav 'blue' and/or German blau 'blue'.

- Names translatable as 'big / great / large river' also appear repeatedly, such as in $\Rightarrow$ Dnestr, $\Rightarrow$ Guadalquivir, $\Rightarrow$ Velikaja, or (not in my list) Lielupe (Latvia) and Storå (Denmark). One of the major rivers of Ireland combines both possibilities as it is called Blackwater in English and An Abhainn Mhór 'the great river' in Irish.

- Quite a few river names seem to be interpretable as animal terms, cf. in our list $\Rightarrow$

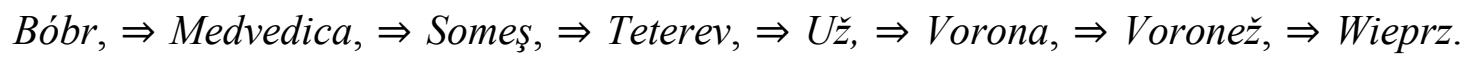
More examples of rivers homonymous with animal names are cited by Rohlfs (1960: 14-18) and Dauzat et al. (1978: 1f.). For a reason that escapes me, associations with

\footnotetext{
${ }^{197}$ In this case we know for sure that the river was named after the Dutch Royal house and that the similarity to a colour term is accidental.

${ }^{198}$ Niger appears to resemble the Latin word for 'black', but was in fact more probably derived from the Tuareg noun egărew 'river'.
} 
the wolf seem to be particularly popular: Ancient Greek sources cite several rivers named Lykos 'wolf', as there are some German torrents called Wolfsbach, a Loup in France, a Río Lobos in Spain, a Vilka in Lithuania, and a Vuka (ancient Ulca) ${ }^{199}$ in Croatia. Several Wolf Rivers also exist in North America, one of which flows into a Fox River.

- Among the rivers considered in this paper, there are a few others whose meanings seem to be transparent in various ways: $\Rightarrow$ Berezina, $\Rightarrow$ Dalälven, $\Rightarrow$ Kemijoki, $\Rightarrow$ Lu$g a, \Rightarrow M e \check{a}$.

What I suggest here is that the semantic fields cited above are not only common motives for the initial coinage of river names, but also, perhaps more typically, favourite semantic targets for folk-etymological reinterpretations of existing names. I assume particularly for the animal names that the apparent meanings are not normally the original ones but came into being by the inclination of speakers to assimilate uninterpretable names to common words of their language. ${ }^{200}$ The same may also be true for many of the apparent colour names. It would be a worth-wile endeavour to investigate whether any geophysical justification for the colour names can be found, e. g. in the case of the 'white' / 'black' couples. As far as I see, no justification of that kind is evident.

I wish to note in passing that colour and animal terms are common naming motives, or common targets for folk-etymologies, also with other geographical objects such as countries ${ }^{201}$, seas $^{202}$ and mountains. ${ }^{203}$

\section{Head and core elements of proper names}

A common pattern of change to be observed in names, as in all kinds of words, is the recomposition with another element. Recomposition is an antagonist to phonetic erosion which would otherwise continually shorten all words. In toponyms, recomposition typically means that a core element that is no longer understood is expanded by a head element that is semantically transparent at the time of composition. I am adopting here the principle expressed by Vennemann (2003: 39) who states that head and core elements of toponyms usually derive from different chronological layers, the core element being the older one. Examples of toponyms composed in this way are very easy to find. A few illustrations:

\footnotetext{
${ }^{199}$ Cf. Schramm (1981: 409f.), who assumes a folk-etymological association for this name.

${ }^{200}$ I do not share the view expressed by Schwarz (1961: 98f.) who believes that people of ancient times were still apt to give rivers the names of animals, a faculty that, as he thinks, was lost later.

${ }^{201}$ Cf. Belarus, Colorado (US state), Erythrea, Greenland, Lebanon (Semitic *lbn 'white'), Melanesia, Montenegro, Sudan (Arabic sūdān 'blacks, negroes').

${ }^{202}$ Cf. White Sea, Black Sea, Red Sea.

${ }^{203}$ I have collected examples only from Germany. Some German mountains whose names resemble colour terms are: Blauen, Braunenberg, Gelber Berg, Goldberg, Grauenstein, Grünten, Rothaargebirge, Schwarzwald, Weißer Stein. A choice of mountains whose names resemble animal terms are: Adlerfels, Ameisenberg, Bachenberg, Bärenberg, Biberkopf, Dachsberg, Drachenfels, Ebersberg, Eselsberg, Falkenstein, Fuchseck, Gänsehals, Geiersberg, Geißkopf, Habichtswald, Hahnenbogen, Hasenhorn, Hengstberg, Hirschberg, Hohenkarpfen, Hühnerküppel, Hummelsberg, Hundsrücken, Käfernberg, Kälberberg, Katzenbuckel, Köterberg, Kuhberg, Löwenburg, Marderberg, Ochsenkopf, Otterberg, Pferdskopf, Rabenkuppe, Rehhecke, Rindalphorn, Roßberg, Sauberg, Schafkopf, Schneckenstein, Schweinsberg, Taubenkopf, Tierberg, Vogelsberg, Wolfskopf, Wurmberg, Ziegenkopf. One can see that the most important colours as well as almost all conceivable animals serve as name providers for mountains. In several of these instances, the modern name is a demonstrable reinterpretation of a PreGerman name. In most of the other instances, I would suspect this as well, even if it cannot be demonstrated.
} 
- The river $\Rightarrow$ Guadiana $<$ Arabic $w \bar{a} d \bar{l}$ 'valley' + Ana $[s]$ (older and intransparent).

- Many names of German rivers or torrents are composed from an older element expanded by -bach 'brook' or - $a(h a)$ (an obsolete word for 'river', $\Rightarrow$ March) (cf. Krahe 1964: 19).

- Several names of Lithuanian rivers terminate in -upe (Barupe, Laukupè, $\Rightarrow$ Šešupé, etc.), where the Lithuanian noun upe 'river' was composed with an older core element.

- Several Latin or Celtic (and later intransparent) names of towns in Germany were later expanded by the element Burg 'castle, borough', such as Augusta > Augs-burg, Beda > Bit-burg, Gontia > Günz-burg, Lopodunum > Laden-burg, Regino > Regens-burg.

- Numerous British place names are composed of an incomprehensible core element and a head element that is still (more or less) transparent, such as -ton ('town'), -ham ('home') or -borough / -burgh.

- Several English country names were expanded by the noun land, such as Ireland $(<$ Irish Éire + land) and similarly England, Finland, Poland, etc.

\section{$9 \quad$ Recurring elements in river names}

We can assume that compounding as described in the preceding section has occurred in the European river names at all times. This should result in recurring prefixes or suffixes originating from name heads, the most recently added elements. ${ }^{204}$ Such recurring affixes can indeed be found. The following are among the most convincing examples:

- The most striking recurring element is a prefix $* d\llcorner n$ - which appears particularly in the names of some of the largest rivers of Europe $(\Rightarrow$ Dnepr,$\Rightarrow$ Dnestr,$\Rightarrow$ Don,$\Rightarrow$ Donau, $\Rightarrow$ Donec, $\Rightarrow$ Dunajec, $\Rightarrow$ Zapadnaja Dvina; less probably also as a noninitial element in $\Rightarrow$ Rhône $<$ Rhodanus). It is generally agreed upon that this prefix represents a term for 'river' of some Indo-European language. It is most commonly considered as specifically Iranian (cf. Ossetic don 'river', Avestan dānuš 'river'), but an explanation from Dacian has also been suggested (Schramm 1973: 58-60), and the existence of an (unattested) Celtic noun *dān (don) 'river' has been suspected from the existence of rivers with this name in Britain (Förster 1941: 141-148). It should also be noted that the constituent order head-dependent as evidenced by the $d \backsim n$-names is not typical for any known Iranian language. Be that as it may, it is very probable that names such as Dnepr, Dnestr, Donau etc. are compounds with an Indo-European head element $d\llcorner n$-, the remaining parts such as ( ) pr-, (Ystr-, (u)vi- being the original name cores. In agreement with what was said above, the core elements need not be explainable from the same language as the head element, as has often been believed, ${ }^{205}$ but are, in fact, likely to be more ancient.

\footnotetext{
${ }^{204}$ Conversely, shared elements of river names are best explained as being fused name heads. A fundamentally different and, in my view, bizarre proposal was made by Schramm (1998) who believes that the name inventors deliberately constructed a network of name references among the river names of Europe, so that, e.g., the name of the $\Rightarrow$ Dnepr would have been coined as a compound of $\Rightarrow$ Donau and $\Rightarrow$ Prut, because the name inventors conceived it as a Prut-like kind of Danube (p. 29; and similarly for various other names).

${ }^{205}$ It has been a common approach to explain all these names as purely Iranian.
} 
- Another recurring element seems to be *mar- in $\Rightarrow$ Marica, $\Rightarrow$ Morava (twice), $\Rightarrow$ Mur and $\Rightarrow$ Mureş. This element is most commonly (e. g. by Krahe 1954: 64f. and 1964: 47; Georgiev 1961: 93; Duridanov 1996: 221) identified with IndoEuropean aquatic terms such as Latin mare 'sea', which presupposes a semantic fluctuation between the concepts 'sea' and 'river'. By contrast, Detschew (1957: 288f.) preferred to see here an Indo-European term for 'big' (represented in Old Irish már).

- Names such as $\Rightarrow$ Ebro, $\Rightarrow$ Évros and $\Rightarrow I b a r$, alongside numerous names of smaller rivers that are not discussed here, are given by Vennemann (2003: 820835; cf. also Krahe 1964: 55-57) a Pre-Indo-European explanation (comparison with Basque $i b a i \sim i b a r$ 'river'). We may possibly add the core element *-epr that is left from Dnepr after its initial head word, that we discussed above, has been removed (a suggestion already considered, but rejected, by Fasmer (1964-87, I: 518).

- Another recurring hydronymic element is $* i s r$ - or $*_{i s t r}{ }^{206}$, e. g. in $\Rightarrow I s a r, \Rightarrow$ Isère, $\Rightarrow$ Oise ( $<$ Isara) and Istros (ancient name of the $\Rightarrow$ Donau); less likely also in $\Rightarrow$ Struma as well as name internally in $\Rightarrow$ Bistritga, $\Rightarrow$ Elster $<$ Alestra and $\Rightarrow$ Weser. Vennemann (2003: 489f.) suggests a connection to a (reconstructed) Basque morpheme *iz- 'water'.

- An element $* d(u) r$ - might be separable from at least some of the names $\Rightarrow$ Duero, $\Rightarrow$ Drau, $\Rightarrow$ Dordogne, $\Rightarrow$ Drin, $\Rightarrow$ Drina, $\Rightarrow$ Drut,$\Rightarrow$ Durance and $\Rightarrow$ Turia (cf. Dauzat et al. 1978 s.v. Dore). Krahe (1964: 44f. and 55) relates this element to Sanskrit dravati 'to run', a verb for which no cognates outside Indo-Iranian are otherwise known. Volm (1958: 6f.) confuses this element with a Celtic root *dubro- 'water' (Irish dobhar, Welsh $d w f r$, Breton dour), which in turn is usually seen as underlying another set of river names including Engl. Dover and Germ. Tauber (Krahe 1964: 89f.).

- Dobrodomov (1987) suggests that the ending $-k / g\urcorner$ of some Russian and Ukrainian river names including $\Rightarrow$ Ingul, $\Rightarrow$ Oskol, $\Rightarrow$ Vorskla represents a former noun for 'river' of Altaic origin (cf. Old Turkic qol 'valley', Mongolian gol 'river').

- Numerous river names of Romania share the termination -eş/iş: $\Rightarrow$ Argeş, $\Rightarrow$ Criş, $\Rightarrow$ Mureş, $\Rightarrow$ Someş, $\Rightarrow$ Timiş, as also smaller rivers not in our list (Agriş, Aluniş, Arieş, Babeş, Figheş, Ghereş, Sebeş and many others). This seems to be an instance of a former name head of a regionally restricted language (Dacian?).

\section{Traditional views on the genetic affiliation of river names}

Most scholars have believed that the river names of Europe are predominantly of IndoEuropean origin. A classic and still very influential work on the topic is Krahe's (1964), whose ideas have been closely followed not only by his German school of hydronymists (e. g. Schmid and Udolph) but also beyond (e. g. Kitson 1996). First, Krahe discovered that a number of roots recur repeatedly among the European river names. Second, he believed that these

\footnotetext{
206 - $t$ - can be epenthetic, the development $-s r->-s t r$ - being regular for some Indo-European languages (Germanic, Slavonic).
} 
roots can be equated with items of Indo-European appellative vocabulary. The etymologies proposed by Krahe involve a large number of Indo-European terms signifying water or qualities of water, in fact a larger number of terms than survive in any single Indo-European daughter language. This made him suppose that these names derived from a layer close to the proto-language, in which the sum of all water-related terms found in the later Indo-European daughter languages were still in existence. ${ }^{207} \mathrm{He}$ called this layer "alteuropäisch" ('OldEuropean').

Schmid (1968), one of Krahe's pupils, drew the further conclusion that Central Europe, the area in which most of Krahe's (presumed) Indo-European river names were found, was the probable homeland of the Indo-European peoples. ${ }^{208}$

Georgiev (1966) pursued a similar approach as I do here by examining the names of 26 European rivers that exceed $500 \mathrm{~km}$ in length. He, as did Krahe, believed to find Indo-European explanations for most of them and concluded: "Die Herkunft aller dieser Flussnamen ist also klar: es stecken darin altertümliche i[n]d[o]e[uropäische] Wörter, die 'Wasser', 'Fluss', 'Strom', 'Sumpf', 'Marsch' u. dgl. bedeuten" (Georgiev 1966: 191).

There has, naturally, been some criticism of the Old-European approach. Vennemann is the most prominent opponent. He (Vennemann 2003) suggested that many hydronyms do not derive from Indo-European, but rather from a prehistoric language family he calls "Vasconic" which predates the Indo-European invasion and whose last survivor is modern Basque. This theory has raised a fair amount of discussion which is not yet converging towards any consensus. ${ }^{209}$ Blong (2003) has searched a compromise between both approaches by proposing that European hydronyms are in part of Indo-European and in part of Vasconic origin.

I will not endeavour to discuss the numerous individual arguments brought forward by both parties. Instead, I wish to introduce an entirely new argument into the discussion, namely a glottochronological one. I argue that, from a glottochronological point of view, most of the river names are unlikely to be Indo-European. While I am not making any positive statement concerning a possible relationship to Basque, my conclusions are in any case less compatible with Krahe's than with Vennemann's theory.

\footnotetext{
207 "Hinsichtlich der Semasiologie und Etymologie geht die urtümlichste und zweifellos älteste Namenschicht von sog[enannten] 'Wasserwörtern' aus [...], mit zahllosen feineren und feinsten Bedeutungsschattierungen, wie sie dem frühen Menschen bei seiner genaueren Naturbeobachtung in reichem Maße zu Gebote standen und wie wir Heutige sie in solchem Umfang kaum noch kennen oder nachempfinden können" (Krahe 1964: 34).

The lexemes compared with the European hydronyms are often taken from geographically remote branches of Indo-European: "[...] many, perhaps most, of these watery elements survived as lexical items only in eastern Indo-European languages not in European ones. It follows that the naming-system was in operation since before the eastern languages separated from the western continuum" (Kitson 1996: 86).

${ }^{208} \mathrm{Schmid}$ and others of Krahe's adherents have often stated that "Old-European" hydronyms are scarce in (presumed) fringe areas of the Indo-European world, such as India, Anatolia, or the Mediterranean. To the best of my knowledge, it has never been clarified whether there is really a lack of river names in these areas for which Indo-European etymologies could be suggested, or only a lack of investigation of the river names of these areas. ${ }^{209}$ There is even an article "Vasconic substratum theory" devoted to the topic in the English Wikipedia.
} 


\section{Computation and conclusion}

Out of the 210 rivers under study, 92 are attested in classical Greek or Latin sources. I consider only these rivers in the following, assuming that the names that happen not to be attested from antiquity would show the same statistical properties as the attested ones. ${ }^{210}$

The ancient name has survived in 78 instances and been replaced in 10 instances. The four instances of rivers with alternate ancient names only one of which has survived (Donau, Kuban', Miño, Saône) are counted half, so we get $78+4 / 2=80 .{ }^{211}$ This means that $80 / 92=87 \%$ of the ancient names have been preserved through 2000 years.

Under Swadesh's hypothesis, namely the assumption that the preservation rate was essentially the same in the prehistoric periods, we can estimate the distribution of name ages. The result is an exponential distribution which, however, as was explained in section 2, provides no exact points in time but only lower limits for the age estimates. This is why I add "at least" to the statements that follow. We thus find that:

- $80 / 92=87 \%$ of the river names have existed for 2000 years (based on direct observation).

- $(80 / 92)^{2}=76 \%$ of the river names are likely to have existed for at least 4000 years.

- $(80 / 92)^{3}=66 \%$ of the river names are likely to have existed for at least 6000 years.

- $57 \%$ of the river names are likely to have existed for at least 8000 years.

- $50 \%$ of the river names are likely to have existed for at least 10000 years.

- $43 \%$ of the river names are likely to have existed for at least 12000 years.

- $38 \%$ of the river names are likely to have existed for at least 14000 years.

- $33 \%$ of the river names are likely to have existed for at least 16000 years.

- $28 \%$ of the river names are likely to have existed for at least 18000 years.

- $25 \%$ of the river names are likely to have existed for at least 20000 years.

Put differently, $50 \%$ of the present names are likely to have existed for at least $2000 * \log 0.5$ $/ \log (80 / 92)=9900$ years $=$ since $7900 \mathrm{BC}$.

It should be emphasized that these figures presuppose a regular transmission of the names that was not disrupted by extraordinary events. Assume, for the sake of the argument, that some charismatic personality had rebaptized all European river names in about $2000 \mathrm{BC}$. This fact would not become evident from my method, and my computations would be misleading. Such

\footnotetext{
210 There is a methodological problem that should be mentioned here. The probability for an ancient river to have been identified is higher if its name was not replaced because name similarity can be one of the arguments to support an identification. For example, the identification of modern $\Rightarrow$ Bosna with the ancient Bathinus heavily relies on the name form, and this identification would seem much less certain, had the ancient name been a different one. In that case, I would not have counted this river as "no match" rather than "match", but I would rather have excluded it from my statistics, which is what I do for all river names without (evident) ancient attestation. This effect should lead, in theory, to a systematic overestimation of the name preservation rate.

The impact of this problem is hard to quantify. I hope that the effect is on the whole insignificant and that it will be largely cancelled out by the fact that my dates are not meant as exact points in time but only as lower limits for the age estimations.

${ }^{211}$ Instead of asking how many of the ancient names have survived, it could be asked how many of the modern names are ancient. By that logic, we would count a full match when one of two alternate old names has survived (as in $\Rightarrow$ Donau) but only a half match when one of two alternate modern names is ancient (as in $\Rightarrow$ Vardar). The global result should be essentially the same. I preferred the other way of counting because the modern names are known more completely than the ancient names, so that we are able to judge the fate of a given ancient name with more precision than to judge the age of a given modern name.
} 
an event is of course unlikely, at least as unlikely as would be a deliberate change of word forms by an individual which would have interrupted the natural phonetic change of languages. But there is another extraordinary event that was real. This is the last ice age which lasted (subject to definition) until about 8000 BC. During that time, the Northern part of Europe was uninhabited. This implies that, even though my formula mechanically predicts some of the river names to be 20000 years or older, the repopulation of parts of Europe after the ice age is an obvious limit to the real age of river names.

What are the conclusions concerning a possible Indo-European origin of the river names? In the northern part of Europe, the names cannot predate the hard limit given by the repopulation after the ice age, but I assume that a significant number of them derive from exactly that time. By contrast, most traditional datings fix the Indo-European proto-language at only 3000 or 4000 BC. An earlier dating was suggested by Renfrew (2000) and by Dixon (1997: 84), both of whom linked the spread of Indo-European to the introduction of neolithic culture into Europe, to be dated about 7000 BC. I am personally more inclined towards Renfrew's and Dixon's than the majorities view for reasons not to be discussed in this place. But even under that assumption, it appears that the names of most larger European rivers are too old to be of IndoEuropean origin. This is particularly so as the Indo-European territory could not yet have covered the whole of Europe at the time when the proto-language was spoken. Therefore, most of the river names are likely to derive from Pre-Indo-European languages. These names are our best, and perhaps our only witnesses of the extinct paleolithic languages that must have been spoken in Europe before the massive spread of the Indo-European languages within (or into) this continent took place.

\section{References}

Balaišis, Vytautas (1987): "Zur deutschen Bezeichnung des Flusses Nemunas (Memel) und seiner Etymologie". Kalbotyra 38: 23-28.

Battisti, Carlo (1962): "Atesis". Revue de Linguistique Romane 26: 25-33.

de Bernardo Stempel, Patrizia (1994): "Zum gallischen Akzent: eine sprachinterne Betrachtung". Zeitschrift für Celtische Philologie 46: 14-35.

Bichlmeier, Harald (2009): "Bairisch-österreichische Orts- und Gewässernamen aus indogermanistischer Sicht". Blätter für Oberdeutsche Namenforschung 46: 3-63.

Biolik, Maria (1996): Die Namen der fließenden Gewässer im Flußgebiet des Pregel. Stuttgart: Steiner. (= Hydronymia Europaea 11).

Blong, Matthew H. (2003): "On the debated origins of the Old-European hydronymy". Beiträge zur Namenforschung 38: 401-427.

Borchers, Ulf (2005): Das Flussgebiet der Unterweser und der mittleren Weser. Stuttgart: Steiner. (= Hydronymia Germaniae 18).

Borchers, Ulf 2006): Große Flüsse auf dem Gebiet der Bundesrepublik Deutschland. Stuttgart: Steiner. (= Hydronymia Germaniae Supplement).

Ciocan-Ivănescu, R./Ivănescu, G. (1969): "Etymologie de l'hydronyme roumain Jijia". In: Hornung, Herwig H. (ed.): Disputationes ad montium vocabula aliorumque nominum significationes pertinentes. 10. Internationaler Kongress für Namenforschung - Abhandlungen, vol. II. Wien, Wiener Med. Akademie: 481-487.

Clarysse, Willy (1997): "Greek accents on Egyptian names". Zeitschrift für Papyrologie und Epigraphik 119: 177-184.

Coutinho, Ismael de Lima (1967): Pontos de Gramática Histórica. Rio de Janeiro: Livraria Acad. 
Dauzat, Albert (1926): Les noms de lieux. Origine et évolution. Paris: Delagrave.

Dauzat, Albert et al. (1978): Dictionnaire étymologique des noms de rivières et de montagnes en France. Paris: Klincksieck.

Deroy, Louis/Mulon, Marianne (1992): Dictionnaire de noms de lieux. Paris: Robert.

Detschew, Dimiter (1957): Die thrakischen Sprachreste. Wien: Rohrer.

Dixon, Richard M.W. (1997): The rise and fall of languages. Cambridge: Cambridge University Press.

Dobrodomov, Igor' G. (1987): "Vorskla". Russkaja Reč' 1987/2: 114-118.

Duridanov, Ivan (1975): Die Hydronymie des Vardarsystems als Geschichtsquelle. Köln: Böhlau.

Duridanov, Ivan (1996): "Zur Deutung der Flussnamen Marisia-Mureş, Marica, Someş, Alutus-Olt, Dānuvius-Dunăre". Balkansko Ezikoznanie / Linguistique Balkanique 38: 221224.

Duridanov, Ivan (1999): "Zur dakischen Hydronymie". In: Eggers, Eckhard et al. (eds.): Florilegium linguisticum. Festschrift für Wolfgang P. Schmid zum 70. Geburtstag. Frankfurt: Lang. 95-99.

Dyen, Isidore/James, A.T./Cole, J.W.L. (1975): "Language Divergence and Estimated Word Retention Rate". In: Dyen, Isidore (ed.): Linguistic Subgrouping and Lexicostatistics. The Hague, Mouton: 181-207.

Dyen, Isidore/Kruskal, Joseph B./Black, Paul (1992): An Indoeuropean Classification: A Lexicostatistical Experiment. Philadelphia: American Philosophical Society.

(= Transactions of the American Philosophical Society 82/5).

Eichler, Ernst (1981): "Alte Gewässernamen zwischen Ostsee und Erzgebirge". Beiträge zur Namenforschung 16: 40-54.

Ekwall, Eilert (1928): English River-Names. Oxford: Clarendon.

Fasmer, Maks [Vasmer, Max] (1964-1987): Etimologičeskij slovar' russkogo jazyka, 4 volumes. Moskva: Progress.

Förster, Max (1941): Der Flußname Themse und seine Sippe. Studien zur Anglisierung keltischer Eigennamen und zur Lautchronologie des Altbritischen. (= Sitzungsberichte der Bayerischen Akademie der Wissenschaften, Phil.-hist. Abt. 1941/1).

Georgiev, Vladimir (1960): Balgarska etimologija i onomastika. Sofija: BAN.

Georgiev, Vladimir (1961): "Theiss, Temes, Maros, Szamos (Herkunft und Bildung)". Beiträge zur Namenforschung 12: 87-95.

Georgiev, Vladimir (1966): "Die europäische Makrohydronymie und die Frage nach der Urheimat der Indoeuropäer". In: Blok, Dirk P. (ed.): Proceedings of the Eighth International Congress of Onomastic Sciences. The Hague, Mouton: 188-195.

Guérios, Rosário F. Mansur (1956): "O Romanço Moçarábico Lusitano". Letras 5/6: 123153.

Hengst, Karlheinz (2001): "Eigennamen und Sprachkontakt in Osteuropa. Ein Modellfall: Der geographische Name Samara". Onoma 36: 71-90.

Holzer, Georg (2007): Historische Grammatik des Kroatischen. Einleitung und Lautgeschichte der Standardsprache. Frankfurt: Lang.

Ionescu, Ioan (1971): "Despre originea şi semnificaţia etimologică a toponimicului Argeş". Limba Română 20: 335-337.

Jung, Edmond (1970): "Réflexions sur le nom Sequana". Revue des Études Latines 47: 434461.

Kettner, Bernd-Ulrich (1973): Die Leine und ihre Nebenflüsse bis unterhalb der Einmündung der Innerste. Wiesbaden: Steiner. (= Hydronymia Germaniae 8).

Kitson, Peter R. (1996): "British and European river-names". Transactions of the Philological Society 94: 73-118. 
Krahe, Hans (1954): Sprache und Vorzeit. Europäische Vorgeschichte nach dem Zeugnis der Sprache. Heidelberg: Quelle/Meyer.

Krahe, Hans (1960): "Die germanische Lautverschiebung und der Neckar". Beiträge zur Namenforschung 11: 144-147.

Krahe, Hans (1964): Unsere ältesten Flußnamen. Wiesbaden: Harrassowitz.

Laso, A. Moralejo (1966): "Los antiguos nombres de los ríos lenoneses Esla y Orbigo". In: Blok, Dirk P. (ed.): Proceedings of the Eighth International Congress of Onomastic Sciences. The Hague, Mouton: 295-303.

Le Gall, Joël (1953): Le Tibre. Fleuve de Rome dans l'antiquité. Paris: Univ. de France.

Mann, Stuart E. (1977): An Albanian Historical Grammar. Hamburg: Buske.

Meyer-Lübke, Wilhelm (1930): "Etymologisches". Modern Philology 27: 415-417.

Nepokupnyj, Anatolij P./Stryžak, O.S./Cilujko, K.K. (eds.) (1979): Slovnyk Hidronimiv Ukraïny. Kyïv: Nauk. Dumka.

Otin, Evgenij S. (1989): "Kalitva". Russkaja Reč' 1989/2: 125-129.

Otkupščikov, Jurij V. (1974): "Iz drevnej gidronimiki". Acta Linguistica Academiae Scientiarum Hungaricae 24: 277-292.

Penzl, Herbert (1985): "Zur gotischen Urheimat und Ausgliederung der germanischen Dialekte". Indogermanische Forschungen 90: 147-167.

Peust, Carsten (2010): Die Toponyme vorarabischen Ursprungs im modernen Ägypten. Göttingen: Seminar für Ägyptologie und Koptologie. (= Göttinger Miszellen Beiheft 8)

Pokorny, Julius (1940): "Zur Urgeschichte der Kelten und Illyrier". Zeitschrift für Celtische Philologie 21: 55-166.

Pospelov, Evgenij M. (1998): Geografičeskie nazvanija mira. Toponimičeskij slovar'. Moskva: Russkie slovari.

Reichardt, Lutz (1985): "Donau". Blätter für Oberdeutsche Namenforschung 22: 33-39.

Reichert, Hermann (2005): "Germanien in der kartographischen Sicht des Ptolemaios". In: Rasch, Gerhard/Zimmer, Stefan (eds.): Antike geographische Namen nördlich der Alpen. Berlin, de Gruyter: 249-292.

Renfrew, Colin (2000): "10,000 or 5,000 years ago? - Questions of time depth". In: Renfrew, Colin et al. (eds.): Time Depth in Historical Linguistics, vol. II: Cambridge, McDonald Inst. for Archaeological Research 413-439.

Rohlfs, Gerhart (1960): "Europäische Flußnamen und ihre historischen Probleme". Heuss, Theodor (ed.): VI. Internationaler Kongress für Namenforschung. München: 1-28.

Schmid, Wolfgang P. (1968): Alteuropäisch und Indogermanisch. Abhandlungen der Akademie der Wissenschaften und der Literatur Mainz, Geistes- und sozialwiss. Klasse 1968/6.

Schmid, Wolfgang P. (1976): Review of Schramm (1973). Indogermanische Forschungen 81: 435-441.

Schramm, Gottfried (1973): Nordpontische Ströme. Göttingen: Vandenhoeck/Ruprecht.

Schramm, Gottfried (1981): Eroberer und Eingesessene. Geographische Lehnnamen als Zeugen der Geschichte Südosteuropas im ersten Jahrtausend n. Chr. Stuttgart: Hiersemann.

Schramm, Gottfried (1998): "Vernetzte Stromnamen. Stufen eines Ausstiegs aus alteuropäischer Normalität zwischen Ostalpen und Nordkaukasus". Beiträge zur Namenforschung 33: $15-38$.

Schwarz, Ernst (1961): Die Ortsnamen der Sudetenländer als Geschichtsquelle. $2^{\text {nd }}$ ed. München: Lerche.

Shevelov, George Y. (1979): A historical phonology of the Ukrainian language. Heidelberg: Winter.

Sperber, Rüdiger (1970): Das Flussgebiet des Mains. Wiesbaden: Steiner. (= Hydronymia Germaniae 7). 
Swadesh, Morris (1952): "Lexico-statistic dating of prehistoric ethnic contacts, with special reference to North American Indians and Eskimos". Proceedings of the American Philosophical Society 96: 452-463.

Swadesh, Morris (1955): "Towards Greater Accuracy in Lexicostatistic Dating". International Journal of American Linguistics 21: 121-137.

Talbert, Richard J.A. (ed.) (2000): Barrington Atlas of the Greek and Roman World, 2 text vols. and 1 map vol. Princeton: Princeton Univ. Press.

Tolstoj, Nikita I. (1984): "Desna - «dextra»?". Gorškova, Klavdija V. (ed.): Istorija russkogo jazyka v drevnejšij period. Moskva, Univ.: 189-223.

Udolph, Jürgen (1981/83): "Slav. *bystrica in Appellativa und Namen". In: Hursky, Jacob P. (ed.): Studies in Ukrainian Linguistics in honor of George Y. Shevelov (Annals of the Ukrainian Academy of Arts and Sciences in the U.S. 15). New York: 325-336.

Udolph, Jürgen (1983a): "Zum Namen des Südlichen Bug". Indogermanische Forschungen 88: 98-108.

Udolph, Jürgen (1983b): "Gewässernamen der Ukraine und ihre Bedeutung für die Urheimat der Slaven". In: Olesch, Reinhold (ed.): Slavistische Studien zum IX. internationalen Slavistenkongress in Kiev 1983. Köln, Böhlau: 579-595.

Udolph, Jürgen (1990): Die Stellung der Gewässernamen Polens innerhalb der alteuropäischen Hydronymie. Heidelberg: Winter.

Udolph, Jürgen (2004): "Gewässernamen". In: Brendler, Andrea/Brendler, Silvio (eds.): $\mathrm{Na}$ menarten und ihre Erforschung. Hamburg, Baar: 329-345.

Vennemann, Theo (2003): Europa Vasconica-Europa Semitica. Berlin: de Gruyter.

Volm, Matthew H. (1958): Ist der Fluszname "Rhein" keltischen Ursprungs? Charlottesville: Univ. of Virginia Press.

Wahlberg, Mats (2003): Svenskt ortnamnslexikon. Uppsala: Språk- och Folkminnesinst.

Wauer, Sophie (1999): Das Flussgebiet der Havel. Stuttgart: Steiner. (= Hydronymia Germaniae 17).

Wiesinger, Peter (1994): "Die Ortsnamen Österreichs in makrotoponymischer Sicht". In: Debus, Friedhelm (ed.): Zu Ergebnissen und Perspektiven der Namenforschung in Österreich. Heidelberg, Winter: 51-169.

Wissowa, Georg et al. (eds.) (1894-2000): Paulys Realencyklopädie der classischen Altertumswissenschaft. Stuttgart: Metzler.

Zinsli, Paul (1976-): Ortsnamenbuch des Kantons Bern. Bern: Francke. 